\title{
Gypsum and hydrohalite dynamics in sea ice brines
}

Butler, Benjamin; Papadimitriou, Stathys; Day, Sarah J.; Kennedy, Hilary

\section{Geochimica et Cosmochimica Acta}

DOI:

10.1016/j.gca.2017.06.020

Published: 01/09/2017

Peer reviewed version

Cyswllt i'r cyhoeddiad / Link to publication

Dyfyniad o'r fersiwn a gyhoeddwyd / Citation for published version (APA):

Butler, B., Papadimitriou, S., Day, S. J., \& Kennedy, H. (2017). Gypsum and hydrohalite dynamics in sea ice brines. Geochimica et Cosmochimica Acta, 17-34.

https://doi.org/10.1016/j.gca.2017.06.020

\footnotetext{
Hawliau Cyffredinol / General rights

Copyright and moral rights for the publications made accessible in the public portal are retained by the authors and/or other copyright owners and it is a condition of accessing publications that users recognise and abide by the legal requirements associated with these rights.

- Users may download and print one copy of any publication from the public portal for the purpose of private study or research.

- You may not further distribute the material or use it for any profit-making activity or commercial gain

- You may freely distribute the URL identifying the publication in the public portal ?
}

Take down policy

If you believe that this document breaches copyright please contact us providing details, and we will remove access to the work immediately and investigate your claim. 


\title{
Gypsum and hydrohalite dynamics in sea ice brines
}

\author{
Benjamin M. Butler, ${ }^{\mathrm{a}}$, Stathys Papadimitriou ${ }^{\mathrm{b}}$, Sarah J. Day ${ }^{\mathrm{c}}$, Hilary \\ Kennedy ${ }^{\mathrm{b}}$ \\ ${ }^{a}$ The James Hutton Institute, Craigiebuckler, Aberdeen AB15 8QH, UK \\ ${ }^{b}$ School of Ocean Sciences, Bangor University, Menai Bridge, Anglesey LL59 5AB, UK \\ ${ }^{c}$ Diamond Light Source, Harwell Science and Innovation Campus, Fermi Avenue, Didcot \\ OX11 ODE, UK
}

\begin{abstract}
Mineral authigenesis from their dissolved sea salt matrix is an emergent feature of sea ice brines, fuelled by dramatic equilibrium solubility changes in the large sub-zero temperature range of this cryospheric system on the surface of high latitude oceans. The multi-electrolyte composition of seawater results in the potential for several minerals to precipitate in sea ice, each affecting the in-situ geochemical properties of the sea ice brine system, the habitat of sympagic biota. The solubility of two of these minerals, gypsum $\left(\mathrm{CaSO}_{4} \cdot 2 \mathrm{H}_{2} \mathrm{O}\right)$ and hydrohalite $\left(\mathrm{NaCl} \cdot 2 \mathrm{H}_{2} \mathrm{O}\right)$, was investigated in high ionic strength multi-electrolyte solutions at below-zero temperatures to examine their dissolution-precipitation dynamics in the sea ice brine system. The gypsum dynamics in sea ice were found to be highly dependent on the solubilities of mirabilite and hydrohalite between 0.2 and $-25.0^{\circ} \mathrm{C}$. The hydrohalite solubility between -14.3 and $-25.0^{\circ} \mathrm{C}$ exhibits a sharp change between undersaturated and supersaturated conditions, and, thus, distinct temperature fields of precipitation and dissolution in sea ice, with saturation occurring at $-22.9{ }^{\circ} \mathrm{C}$. The sharp changes in hydrohalite solubility at temperatures $\leqslant-22.9^{\circ} \mathrm{C}$ result from the formation of an ice-hydrohalite aggregate, which alters the structural properties of brine inclusions in cold sea ice. Favourable conditions for gypsum precipitation in sea ice were determined to occur in the region of hydrohalite precipitation below $-22.9{ }^{\circ} \mathrm{C}$ and in conditions of
\end{abstract}


metastable mirabilite supersaturation above $-22.9{ }^{\circ} \mathrm{C}$ (investigated at -7.1 and $-8.2{ }^{\circ} \mathrm{C}$ here) but gypsum is unlikely to persist once mirabilite forms at these warmer $\left(>-22.9^{\circ} \mathrm{C}\right)$ temperatures. The dynamics of hydrohalite in sea ice brines based on its experimental solubility were consistent with that derived from thermodynamic modelling (FREZCHEM code) but the gypsum dynamics derived from the code were inconsistent with that indicated by its experimental solubility in this system. Incorporation of hydrohalite solubility into a 1D thermodynamic model of the growth of first-year Arctic sea ice showed its precipitation to initiate once the incoming shortwave radiation dropped to $0 \mathrm{~W} \mathrm{~m}^{-2}$, and that it can reach concentrations of $9.9 \mathrm{~g} \mathrm{~kg}^{-1}$ within the upper and coldest layers of the ice pack. This suggests a limited effect of hydrohalite on the albedo of sea ice. The insights provided by the solubility measurements into the behaviour of gypsum and hydrohalite in the ice-brine system cannot be gleaned from field investigations at present.

Keywords: Gypsum, Hydrohalite, Solubility, Sea ice, FREZCHEM

\section{Introduction}

2 When sea ice forms in high latitude environments, seawater solutes are 3 expelled from the ice crystal matrix and a concentrated brine forms which be4 comes trapped as inclusions in the sea ice microstructure (Petrich and Eicken, 5 2010). At ice-brine equilibrium, the brine inclusions have a temperaturelatter further governed by the solubility of their related salts (Marion, 2001). The $\mathrm{Na}-\mathrm{K}-\mathrm{Mg}-\mathrm{Ca}-\mathrm{SO}_{4}-\mathrm{Cl}-\mathrm{H}_{2} \mathrm{O}$ system contains $99.4 \%$ of the total dissolved ions in Standard Seawater by mass (Millero et al., 2008), and, as sea ice temperature changes, solid-solution reactions of the brine with the predominantly hydrated salts of these major ions dominate the geochemistry of the system (Gitterman, 1937; Nelson and Thompson, 1954). The combined effect of changing temperature, solute concentration, and mineral (sea salt) solubility in the sea ice brine is that, as sea ice cools, the brines become 
sequentially supersaturated with respect to a suite of minerals. Each mineral in the sequence has a distinct solubility-temperature relationship and, hence, a distinct equilibrium onset temperature of precipitation from the brines between the freezing point of seawater and its eutectic (Gitterman, 1937; Nelson and Thompson, 1954; Marion et al., 1999). These authigenic minerals become part of the heterogeneous sea ice matrix (Light et al., 2003; Dieckmann et al., 2008; Geilfus et al., 2013), contributing to its optical, mechanical, thermal, and structural properties (Assur, 1960; Light et al., 2004; Carns et al., 2015). Precipitation of sea ice minerals also modifies the physicochemical properties of the brine inclusions, including salinity (Butler et al., 2016a) and the inter-ionic ratios of dissolved constituents, thus contributing to the physiological challenges for ice-associated micro-organisms (Thomas and Dieckmann, 2002). Further, mineral precipitation features in the salt mass balance of saline cryogenic systems in past and present polar environments on Earth (Assur, 1960; Light et al., 2009) and other water-bearing planetary bodies (Marion and Kargel, 2008).

In absence of metastable supersaturated conditions (see section 2.3), the suite of minerals that can precipitate within sea ice includes ikaite $\left(\mathrm{CaCO}_{3}\right.$. $\left.6 \mathrm{H}_{2} \mathrm{O}\right)$, mirabilite $\left(\mathrm{Na}_{2} \mathrm{SO}_{4} \cdot 10 \mathrm{H}_{2} \mathrm{O}\right)$, hydrohalite $\left(\mathrm{NaCl} \cdot 2 \mathrm{H}_{2} \mathrm{O}\right)$, gypsum $\left(\mathrm{CaSO}_{4}\right.$. $\left.2 \mathrm{H}_{2} \mathrm{O}\right)$, sylvite $(\mathrm{KCl}), \mathrm{MgCl}_{2} \cdot 12 \mathrm{H}_{2} \mathrm{O}$, and antarcticite $\left(\mathrm{CaCl}_{2} \cdot 6 \mathrm{H}_{2} \mathrm{O}\right)$ at progressively decreasing temperatures. Depending on the exact sequence of mineral precipitates, the eutectic temperature of sea ice can be $-36{ }^{\circ} \mathrm{C}$ (in association with $\mathrm{MgCl}_{2} \cdot 12 \mathrm{H}_{2} \mathrm{O}$; Gitterman, 1937) or $-54{ }^{\circ} \mathrm{C}$ (in association with antarcticite; Nelson and Thompson, 1954).

Ikaite has been identified in natural and experimental sea ice (Dieckmann et al., 2008; Geilfus et al., 2013; Fischer et al., 2013). The solubility of ikaite in sea ice brines has been investigated to $-7.5^{\circ} \mathrm{C}$, and this $\mathrm{CaCO}_{3}$ polymorph can precipitate below $-2{ }^{\circ} \mathrm{C}$ depending on the brine $p \mathrm{CO}_{2}$ (Papadimitriou et al., 2013). Mirabilite solubility in sea ice brines has been investigated to $-20.6{ }^{\circ} \mathrm{C}$ (Butler et al., 2016b). Sea ice brines become supersaturated 
with respect to mirabilite at temperatures $\leqslant-6.4{ }^{\circ} \mathrm{C}$, and its consequent precipitation causes this mineral to become the main sink of $\mathrm{SO}_{4}^{2-}$ in sea ice brines (Marion et al., 1999; Butler et al., 2016b). Gypsum has long been predicted to precipitate from frozen seawater but information on its stability in sea ice brines is less precise than for ikaite and mirabilite. From the major ion composition of residual brine during the freezing of synthetic seawater to its eutectic, Gitterman (1937) inferred that gypsum precipitation should occur at temperatures below $-15{ }^{\circ} \mathrm{C}$. In these experiments, all potential authigenic minerals were allowed to interact with the residual brine to solid-solution equilibrium. More recently, Marion et al. (1999) combined thermodynamic model predictions (FREZCHEM) with experimental analysis of seawater brines seeded with gypsum at $-15,-20$ and $-26{ }^{\circ} \mathrm{C}$, and proposed that gypsum in brines becomes supersaturated at $-22.2{ }^{\circ} \mathrm{C}$ but its precipitation is enhanced below $-22.9{ }^{\circ} \mathrm{C}$ as a result of brine-mirabilitehydrohalite interaction. Specifically, initial removal of $\mathrm{Na}^{+}$and $\mathrm{SO}_{4}^{2-}$ from the brine via mirabilite precipitation between -6.4 and $-22.9{ }^{\circ} \mathrm{C}$ is followed by additional removal of $\mathrm{Na}^{+}$from the brine through hydrohalite precipitation upon further cooling. The large $\mathrm{Na}^{+}$change via hydrohalite precipitation results in brine undersaturation with respect to mirabilite, which dissolves when in contact with the brine. The liberated $\mathrm{SO}_{4}^{2-}$ from mirabilite dissolution enhances the degree of gypsum supersaturation of the brine, resulting in enhanced gypsum precipitation (Gitterman, 1937; Marion et al., 1999). In contrast, the effects of gypsum precipitation on brine composition during seawater freezing were not observed by Nelson and Thompson (1954) due to their experimental protocol, in which the minerals were removed from the natural seawater-derived brine as they formed. The sea ice brine systems represented by the experimental protocols of Gitterman (1937) and Nelson and Thompson (1954) are considered to be representative of the equilibrium crystallisation (hereafter full crystallisation) pathway and the fractional crystallisation pathway, respectively (Marion et al., 1999; Marion and Kargel, 2008; 
Butler and Kennedy, 2015). In an experimental approach representative of the full crystallisation pathway, the brine-mirabilite-hydrohalite interaction was observed during cooling and warming of frozen seawater brines but gypsum was not identified Butler and Kennedy (2015).

Gypsum has recently been identified in experimental and natural sea ice at temperatures between -2 and $-10{ }^{\circ} \mathrm{C}$, and, in view of this, has been proposed as a potential marine deposit in polar seas (Geilfus et al., 2013). This suggests more complex gypsum dynamics in the sea ice system than construed from the available information about the sub-zero temperature field of gypsum stability in seawater brines outlined above. This issue can be elucidated from a more detailed knowledge of the equilibrium gypsum solubility in sea ice conditions.

Here, we investigated the characteristics of the gypsum-brine reaction in sea ice via measurements of the concentration-based (stoichiometric) solubility of this mineral in relevant brines at below-zero temperatures. We sought to identify the conditions that can lead to internal gypsum authigenesis and stability in the large below-zero temperature and salinity ranges of sea ice brines. Knowledge of the hydrohalite dynamics in the sea ice system is essential for this purpose given the common ion effect on mineral stability of the brine-gypsum-mirabilite-hydrohalite interaction outlined earlier and the available information about mirabilite solubility in the sea ice system in our previous work (Butler et al., 2016b). Thermodynamic modelling (Marion et al., 1999) and experimental observations from the Gitterman (1937) and Nelson and Thompson (1954) experiments predict that hydrohalite precipitates in sea ice below $-22.9^{\circ} \mathrm{C}$. Its presence has been identified in laboratory experiments on frozen seawater brines (Butler and Kennedy, 2015) and in sea ice (Light et al., 2003), and affects the optical, mechanical, and frictional properties of sea ice (Light et al., 2004; Carns et al., 2015). From the onset, hydrohalite precipitation is rapid and by $-30{ }^{\circ} \mathrm{C}, 87 \%$ of dissolved $\mathrm{NaCl}$ is removed from the brine as a result (Richardson, 1976). In frozen seawater 
from a starting absolute salinity of $35 \mathrm{~g} \mathrm{~kg}_{\text {solution }}^{-1}$ (in the absence of brine drainage), hydrohalite concentrations can approach $4 \%$ by mass by $-40{ }^{\circ} \mathrm{C}$ (Richardson, 1976; Light et al., 2003). Precipitation of hydrohalite has been shown to be closely associated with enhanced ice formation, which substantially reduces the volume of brine remaining in the ice (Richardson, 1976; Butler and Kennedy, 2015).

The current investigation expands upon recent work on mirabilite solubility in similar conditions (Butler et al., 2016b). The solubility of both gypsum and hydrohalite was measured to a minimum temperature of $-25.0^{\circ} \mathrm{C}$. Because of the large increase in hydrohalite solubility with increasing temperature, the maximum experimental temperature was $-14.3{ }^{\circ} \mathrm{C}$ while that for gypsum solubility was $0.2{ }^{\circ} \mathrm{C}$, with experiments designed to investigate the behaviour of gypsum under conditions equivalent to fractional and full crystallisation pathways. Finally, given the dominance of hydrohalite as a mineral precipitate in cold sea ice, its solubility data set was incorporated into a 1D model of the growth of snow-free first-year sea ice to allow evaluation of its depth distribution and temporal dynamics. The dynamics of gypsum are shown here to be too complex in its dependence on mirabilite and hydrohalite dynamics for this modelling approach.

\section{Methods}

\subsection{Synthetic mineral preparation and synchrotron X-ray powder diffraction}

Synthetic gypsum, hydrohalite, and mirabilite were used for seeding the solid-solution equilibrium reaction and were prepared based on the methods described in Wang et al. (2012), Light et al. (2009), and Butler et al. (2016b), respectively. All synthetic solids were stored in screw-capped bottles; gypsum was stored at room temperature, while hydrohalite and mirabilite were stored at $-20{ }^{\circ} \mathrm{C}$.

The mineralogy of the synthetic solids and of some of the mineral aggregates recovered following solid-solution reaction was characterised at $-30{ }^{\circ} \mathrm{C}$ 
using synchrotron X-ray powder diffraction (XRPD) on Beamline I11 at Diamond Light Source (Harwell Science and Innovation Campus, Oxfordshire, UK). Published cell parameters for hydrohalite (Klewe and Pederson, 1974), gypsum (Boeyens and Ichharam, 2002), and mirabilite (Brand et al., 2009) were used as an initial starting point for LeBail (Le Bail et al., 1988) and Rietveld (Rietveld, 1969) refinements in TOPAS-Academic V6 software (Coelho, 2012). Based on the semi-quantitative (Hillier, 2003) Rietveld refinements, it was established that all batches of synthetic mineral seeds displayed $\geqslant 99 \%$ purity.

\subsection{Closed bottle incubations and brine analysis}

Mineral solubility was determined with closed bottle incubations of natural or synthetic seawater and brines with synthetic solids to solid-solution equilibrium as previously used for this purpose (Mucci, 1983; Papadimitriou et al., 2013; Butler et al., 2016b). The time to solid-solution equilibrium was determined by monitoring the change in $\mathrm{Ca}^{2+}$ with time for gypsum and in $\mathrm{Cl}^{-}$for hydrohalite during incubation (protocols described in section 2.4). Changes sustained within the analytical uncertainty over 1 week were taken to indicate attainment of solid-solution equilibrium. Using this approach the gypsum experiments were incubated for between 41 and 90 days, and hydrohalite experiments incubated for between 24 and 36 days. All incubation experiments were conducted in triplicate, with bottles fully submersed in constant temperature circulating chillers and shaken by hand daily to facilitate exposure of the mineral seed to the bulk solution. Incubation temperatures were controlled by Grant RC 1400G recirculating baths and Grant TX120/TX150 circulators coupled with Grant R2/R3 refrigeration units. Chiller temperatures were monitored at thirty-minute intervals using data loggers (Tinytag aquatic 2 TG4100).

Detailed preparation protocols for the natural and synthetic seawater brines can be found in Butler et al. (2016b). The synthetic seawater and brines were prepared with their major ionic composition $\left(\mathrm{NaCl}, \mathrm{Na}_{2} \mathrm{SO}_{4}\right.$, 
$\mathrm{CaCl}_{2}, \mathrm{MgCl}_{2}, \mathrm{KCl}$ ) a linear function of salinity relative to the recipe of salinity 35 synthetic seawater in Papadimitriou et al. (2016). Natural brines were prepared from local seawater (Menai Strait, $53.1806^{\circ} \mathrm{N}, 4.2333^{\circ} \mathrm{W}$ ) by freezing. The major ion composition (as total ion concentrations) of natural and synthetic experimental solutions was fully quantified before incubation to determine their initial saturation state with respect to the investigated minerals, and after incubation for the determination of the relevant mineral solubility.

The major ion composition of the samples was determined within 4 weeks from sampling, with refrigerated storage before analysis. To eliminate the risk of mineral precipitation during storage, all samples were immediately diluted gravimetrically to a practical salinity of 35 with deionised water. The $\mathrm{Na}^{+}$and $\mathrm{K}^{+}$concentrations were determined by ion chromatography on a Dionex Ion Exchange Chromatograph ICS 2100. The $\mathrm{Mg}^{2+}$ and $\mathrm{Ca}^{2+}$ concentrations were determined by potentiometric titration as described by Papadimitriou et al. (2013). The $\mathrm{Cl}^{-}$concentration was determined by gravimetric Mohr titration with $0.3 \mathrm{M} \mathrm{AgNO}_{3}$ standardised against $\mathrm{NaCl}$ purified by recrystallisation. The $\mathrm{SO}_{4}^{2-}$ concentration was determined by precipitation as $\mathrm{BaSO}_{4}$ in ethylenediaminetetraacetic acid (EDTA) followed by gravimetric titration with $\mathrm{MgCl}_{2}$ (Howarth, 1978). Repeat measurements of the major ion composition of local seawater were used as an internal standard relative to the composition of Standard Seawater (Millero et al., 2008). This comparison provided an estimate of measurement accuracy and precision relative to Standard Seawater, summarised in Table 1.

\subsection{Determination of saturation state and stoichiometric solubility products}

Mineral solubility is defined here as the equilibrium concentration-based (stoichiometric) solubility product at mineral-solution equilibrium, $K_{\mathrm{sp} \text {,gypsum }}^{*}=$ $\left[\mathrm{Ca}^{2+}\right]_{\text {eqm }}\left[\mathrm{SO}_{4}^{2-}\right]_{\text {eqm }}$ and $K_{\mathrm{sp}, \text { hydrohalite }}^{*}=\left[\mathrm{Na}^{+}\right]_{\text {eqm }}\left[\mathrm{Cl}^{-}\right]_{\text {eqm }}$, with brackets denoting total ion concentrations and 'eqm' subscripts denoting equilibrium conditions. The $K_{\mathrm{sp}}^{*}$ is a function of temperature, ionic strength (salinity), 
Table 1: The accuracy and precision of brine analyses estimated using repeat measurements of local seawater (normalised to practical salinity $=35$ ) as an internal standard relative to the composition of Standard Seawater (Millero et al., 2008).

\begin{tabular}{|c|c|c|c|}
\hline & Standard Seawater & Measurements $\pm \sigma$ & \multirow{2}{*}{$\underset{\%}{\Delta \pm \sigma}$} \\
\hline & \multicolumn{2}{|c|}{$\mathrm{mmol} \mathrm{kg}_{\mathrm{sol}}^{-1}$} & \\
\hline $\mathrm{Na}^{+}$ & 468.97 & $470.53 \pm 7.97(n=29)$ & $0.33 \pm 1.70$ \\
\hline $\mathrm{K}^{+}$ & 10.21 & $10.11 \pm 0.05(n=9)$ & $-0.97 \pm 0.49$ \\
\hline $\mathrm{Mg}^{2+}$ & 52.82 & $52.63 \pm 0.54(n=82)$ & $-0.36 \pm 1.02$ \\
\hline $\mathrm{Ca}^{2+}$ & 10.28 & $10.24 \pm 0.14(n=82)$ & $-0.39 \pm 1.36$ \\
\hline $\mathrm{Cl}^{-}$ & 545.87 & $548.48 \pm 6.90(n=38)$ & $0.48 \pm 1.26$ \\
\hline $\mathrm{SO}_{4}^{2-}$ & 28.24 & $28.34 \pm 0.41(n=35)$ & $0.35 \pm 1.45$ \\
\hline
\end{tabular}

and solution composition (Papadimitriou et al., 2013; Butler et al., 2016b), and is hereafter reported as the negative common logarithm $\left(p K_{\mathrm{sp}}^{*}\right)$ on the per $\mathrm{kg}_{\text {solution }}$ basis of the concentration measurements. The $p K_{\mathrm{sp}}^{*}$ values of each mineral were fitted to non-linear functions of temperature ( $T$, in $\mathrm{K}$; eq. 1), using Regression in the Data Analysis ToolPak of Microsoft Excel, with the fitted regression coefficients A to D given in Table 2.

$$
p K_{\mathrm{sp}}^{*}(T)=A+B T+C T^{2}+D T^{3},
$$

The saturation state of samples was determined as $\Omega=\mathrm{ICP} / K_{\mathrm{sp}}^{*}$ (Berner, 1980), with ICP $=$ total ion concentration product prior to seeding (i.e. $\left[\mathrm{Ca}^{2+}\right]\left[\mathrm{SO}_{4}^{2-}\right]$ for gypsum, and $\left[\mathrm{Na}^{+}\right]\left[\mathrm{Cl}^{-}\right]$for hydrohalite) and $K_{\mathrm{sp}}^{*}$ as above. When $\Omega<1$ the initial solution is undersaturated with respect to the mineral. When $\Omega>1$ the initial solution is supersaturated with respect to the mineral. Supersaturation is a metastable state that results in mineral precipitation if suitable nucleation sites are provided. The $\Omega$ values were fitted to non-linear functions of temperature ( $T$, in K; eq. 1), with fitted regression coefficients also given in Table 2. Each solid-solution equilibrium system was defined by the solid phases (including ice, if present) in contact with the brine at equilibrium. For example, a brine attaining equilibrium in contact 
with mirabilite and gypsum will be defined as a brine-mirabilite-gypsum equilibrium system.

The solubility of gypsum was determined in both natural and synthetic brines between 0.2 and $-5.0{ }^{\circ} \mathrm{C}$ to investigate potential matrix effects on the $K_{\mathrm{sp}, \text { gypsum. }}^{*}$. The differences between $p K_{\mathrm{sp} \text {,gypsum }}^{*}$ in natural and synthetic brine experiments over this temperature range were generally within the analytical uncertainty (Figure 1; Table 3) and, therefore, only synthetic brines were used at temperatures below $-5.0{ }^{\circ} \mathrm{C}$. Given the dominance of $\mathrm{Na}^{+}$and $\mathrm{Cl}^{-}$ in the composition of seawater and their tendency to remain as free ions in solution (Millero et al., 2008; Marion and Kargel, 2008), the determination of $K_{\mathrm{sp} \text {,hydrohalite }}^{*}$ only in synthetic brines, as done here, was considered to provide values representative of those in natural seawater-derived brines.

\subsection{Incubation protocols}

Due to the large investigated temperature range and the sequential precipitation of minerals from the brine at various points in this range, three different protocols were employed for the bottle incubations.

Protocol-1: Gypsum solubility. Between 0 and $-6{ }^{\circ} \mathrm{C}$, major ions in seawater and its brines during freezing (absolute salinity, $S_{\mathrm{A}}=35$ to $100 \mathrm{~g}$ $\mathrm{kg}_{\text {solution }}^{-1}$; hereafter, $\mathrm{g} \mathrm{kg}^{-1}$ ) behave conservatively, and so, synthetic solutions were prepared at room temperature with Standard Seawater major ionic ratios and composition (Millero et al., 2008) and were seeded with gypsum. Solutions of $S_{\mathrm{A}} \geqslant 35 \mathrm{~g} \mathrm{~kg}^{-1}$ were incubated within $0.3{ }^{\circ} \mathrm{C}$ of their freezing point, which was estimated using the equation from Millero and Leung (1976).

Protocol-2: Gypsum and hydrohalite solubilities. Protocol-2 was used for incubations between -6 and $-22{ }^{\circ} \mathrm{C}$ to take into account the ice-brinemirabilite reaction, which is documented in this temperature range (Butler et al., 2016b). Conservative seawater brines were prepared $\left(S_{\mathrm{A}}=75\right.$ to 225 $\mathrm{g} \mathrm{kg}^{-1}$ ), cooled to at least $2{ }^{\circ} \mathrm{C}$ colder than their freezing point, and were incubated with mirabilite seed until attainment of ice-brine-mirabilite equi- 


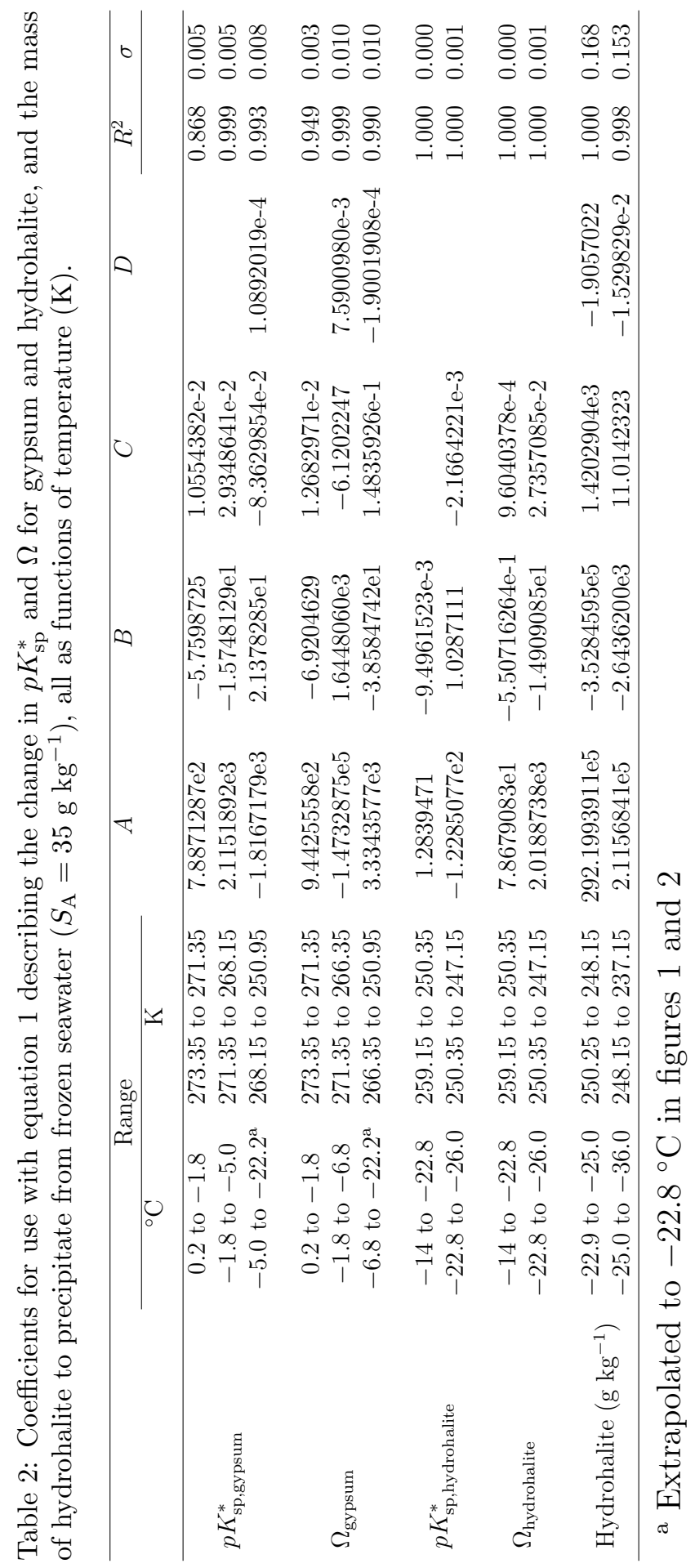


librium. The brine was then extracted by in-situ filtration using WHATMAN $0.2 \mu \mathrm{m}$ syringe filters in line with Teflon tubing extensions. The filtrate was transferred to triplicate $25 \mathrm{ml}$ bottles and was returned to the circulating chiller seeded with either gypsum or hydrohalite until equilibrium had been attained. It is worth emphasising that hydrohalite and ice cannot co-exist above $-22.9{ }^{\circ} \mathrm{C}$ (Marion et al., 1999; Marion and Kargel, 2008), therefore all hydrohalite solubility experiments carried out using protocol-2 represent the extent to which hydrohalite would dissolve (i.e. the degree of undersaturation) in the solutions extracted from an ice-brine-mirabilite equilibrium system.

Protocol-3: Gypsum and Hydrohalite solubilities. Protocol-3 was followed at the coldest experimental temperatures $\left(-23.7\right.$ and $\left.-25.0{ }^{\circ} \mathrm{C}\right)$ to circumvent the substantial reduction in brine volume following hydrohalite precipitation. Conservative seawater brines were prepared to $S_{\mathrm{A}} \sim 225 \mathrm{~g} \mathrm{~kg}^{-1}$ in 500 $\mathrm{ml}$ bottles and were cooled to $-21^{\circ} \mathrm{C}$ when mirabilite seed was added, with ice formation and mirabilite precipitation ensuing. At this stage, the experimental medium included an ice layer at the brine surface and a mirabilite layer at the bottom of the bottle. The ice-brine-mirabilite system was then cooled to either -23.7 or $-25.0^{\circ} \mathrm{C}$. On these occasions, buoyant, irregular, mottled bright white crystal flocs formed during cooling to target temperature and filled the bottle at thermal equilibrium, consistent with reports of ice-hydrohalite aggregates (Nelson and Thompson, 1954; Assur, 1960; McCarthy et al., 2007; Light et al., 2009). The residual brine was trapped within the aggregate and was extracted by drainage into a hole bored into the aggregate with a steel rod. The extracted brine was considered representative of the fractional crystallisation pathway (section 1) because the mirabilite precipitate at the bottom of the bottle was isolated from further reaction with the emergent ice-hydrohalite aggregate and its interstitial brine (previously at equilibrium with the mirabilite). The extracted brine provided the measurements for the determination of $K_{\mathrm{sp}, \text { hydrohalite }}^{*}$ at -23.7 and 
$-25.0^{\circ} \mathrm{C}$, as well as aliquots for further incubations and the determination of the $K_{\mathrm{sp} \text {,gypsum }}^{*}$ at these temperatures. To this end, the extracted brines were incubated with gypsum seed with and without mirabilite seed. Gypsum solubility was therefore determined under two different conditions at -23.7 and $-25.0^{\circ} \mathrm{C}$ : (i) in the absence of mirabilite seed, representative of the fractional crystallisation pathway of restricted brine-mirabilite interaction limited by the ice-hydrohalite aggregate; and (ii) in the presence of mirabilite seed, representative of the full crystallisation pathway of unrestricted brine-mirabilite interaction.

Additional protocol: Gypsum solubility. Although seawater brines become supersaturated with respect to mirabilite at $T \leqslant-6.4{ }^{\circ} \mathrm{C}$, persistence of metastable mirabilite supersaturation has been observed between -7 and $-8{ }^{\circ} \mathrm{C}$ in the absence of mirabilite seed (Butler et al., 2016b). To examine the potential for gypsum precipitation in this narrow temperature window of metastable mirabilite supersaturation in sea ice brines, bottle incubations of conservative solutions were undertaken at $-7.1{ }^{\circ} \mathrm{C}\left(S_{\mathrm{A}}=113.9 \mathrm{~g} \mathrm{~kg}^{-1}\right)$ and $-8.2{ }^{\circ} \mathrm{C}\left(S_{\mathrm{A}}=125.1 \mathrm{~g} \mathrm{~kg}^{-1}\right)$ in an adaptation of protocol-2 that omitted the addition of mirabilite seed. At these temperatures, the solutions were supersaturated with respect to mirabilite and their ionic composition represented that at ice-brine equilibrium. The solutions were seeded with gypsum, the $K_{\mathrm{sp} \text {,gypsum }}^{*}$ was determined at brine-gypsum equilibrium, and mirabilite seed was added to the incubations, resulting in mirabilite precipitation and dissolution of the gypsum precipitate/seed, which remained in excess. The system was then allowed to attain brine-mirabilite-gypsum equilibrium, i.e., the same system investigated using the original protocol-2, but with reversed seeding, from which the $K_{\mathrm{sp} \text {,gypsum }}^{*}$ was again determined.

\subsection{FREZCHEM modelling of gypsum and hydrohalite solubilities}

As a means of relating the experimental $K_{\mathrm{sp} \text {,gypsum }}^{*}$ and $K_{\mathrm{sp} \text {,hydrohalite }}^{*}$ with their thermodynamic counterparts at infinite dilution in pure water, their values were compared with those calculated from the thermodynamic database 
Table 3: The absolute salinity $\left(S_{\mathrm{A}}\right)$ of incubated brines prior to seeding with gypsum, incubation temperature at point of sampling, $\mathrm{Ca}^{2+}$ and $\mathrm{SO}_{4}^{2-}$ concentrations at equilibrium, the resulting measured $p K_{\mathrm{sp}, \text { gypsum }}^{*}$ and $\Omega_{\mathrm{gypsum}}$, and the $\Delta \mathrm{Ca}^{2+}$ observed over the course of each experiment included as a measure of reaction direction $\left(\Delta \mathrm{Ca}^{2+}=\mathrm{Ca}_{\text {eqm }}^{2+}-\mathrm{Ca}_{\text {initial }}^{2+}\right)$. The $S_{\mathrm{A}}$ measured between 0.2 and $-6.0^{\circ} \mathrm{C}$ are at ice-brine equilibrium, while those at $-6.8{ }^{\circ} \mathrm{C}$ and below were measured at ice-brine-mirabilite equilibrium. In each case, equilibrium was attained by gypsum dissolution, evidenced by positive $\Delta \mathrm{Ca}^{2+}$ values. Tabulated errors are calculated as the standard deviation of measurements from triplicate experiments.

\begin{tabular}{|c|c|c|c|c|c|c|c|}
\hline \multirow[t]{2}{*}{ Exp. \# } & \multirow{2}{*}{$\begin{array}{c}S_{\mathrm{A}} \\
\mathrm{g} \mathrm{kg}_{\text {sol }}^{-1} \\
\end{array}$} & \multirow{2}{*}{$\begin{array}{c}\mathrm{T} \\
{ }^{\circ} \mathrm{C} \\
\end{array}$} & $\mathrm{Ca}^{2+}$ & $\mathrm{SO}_{4}^{2-}$ & \multirow[b]{2}{*}{$p K_{\mathrm{sp}, \mathrm{gypsum}}^{*}$} & \multirow[b]{2}{*}{$\Omega_{\text {gypsum }}$} & \multirow{2}{*}{$\begin{array}{c}\Delta \mathrm{Ca}^{2+} \\
\mathrm{mmol} \mathrm{kg}-1 \\
\end{array}$} \\
\hline & & & \multicolumn{2}{|c|}{$\mathrm{mmol} \mathrm{kg}-14$} & & & \\
\hline NG-0 & 35.1 & 0.2 & $27.8 \pm 0.2$ & $48.3 \pm 0.1$ & $2.872 \pm 0.002$ & $0.219 \pm 0.003$ & 17.6 \\
\hline SG-0 & 35.3 & 0.2 & $27.8 \pm 0.2$ & $47.1 \pm 0.7$ & $2.883 \pm 0.005$ & $0.224 \pm 0.007$ & 17.4 \\
\hline NG-1 & 35.3 & -1.1 & $28.1 \pm 0.4$ & $46.4 \pm 0.4$ & $2.884 \pm 0.009$ & $0.228 \pm 0.004$ & 17.7 \\
\hline SG-1 & 35.3 & -1.1 & $28.4 \pm 0.2$ & $46.4 \pm 0.2$ & $2.880 \pm 0.005$ & $0.223 \pm 0.007$ & 18.1 \\
\hline NG-2 & 35.2 & -1.8 & $28.2 \pm 0.1$ & $44.9 \pm 1.0$ & $2.897 \pm 0.011$ & $=0.008$ & 17.7 \\
\hline SG-2 & 35.2 & -1.8 & $28.1 \pm 0.2$ & $44.6 \pm 0.3$ & 2.902 & .004 & 17.4 \\
\hline NG-3 & 53.2 & -2.9 & $31.7 \pm 0.5$ & $58.7 \pm 0.5$ & & .012 & 16.1 \\
\hline SG-3 & 53.0 & -2.9 & $31.0 \pm 0.4$ & $58.5 \pm 1.3$ & 0.014 & 0.004 & 15.7 \\
\hline NG-4 & 70.3 & -3.9 & $32.6 \pm 0.1$ & $68.9 \pm 1.1$ & & & 12.1 \\
\hline SG-4 & 70.4 & -3.9 & $32.1 \pm 0.3$ & $68.6 \pm 0.4$ & & & 11.3 \\
\hline NG-5 & 85.2 & -5.0 & $30.9 \pm 0.2$ & $76.8 \pm 1.7$ & & & 6.0 \\
\hline SG-5 & 85.0 & -5.0 & $30.2 \pm 0.1$ & $78.5 \pm 0.5$ & & & 5.4 \\
\hline SG-6 & 99.7 & -6.0 & & $81.5 \pm$ & & & 7.1 \\
\hline SG-7 & 111.1 & -6.8 & & $73.5 \pm 0.4$ & & & 0.4 \\
\hline SG-8 & 120.6 & -7.9 & $38.9 \pm$ & $65.6 \pm 0.3$ & 2.5 & 005 & 1.0 \\
\hline SG-9 & 131.6 & -8.9 & 42. & $61.6 \pm 0.5$ & & & 1.1 \\
\hline SG-10 & 140.6 & -10.1 & $46.1 \pm 0.1$ & $55.2 \pm 0.1$ & 2.5 & 007 & 1.8 \\
\hline SG-12 & 156.9 & -11.8 & $53.0 \pm 0.3$ & $45.8 \pm 0.6$ & 2.6 & 010 & 2.8 \\
\hline SG-13 & 165.2 & -12.8 & $61.6 \pm 0.3$ & $39.1 \pm 0.2$ & $2.618 \pm 0.001$ & 0.006 & 7.3 \\
\hline SG-14 & 173.8 & -14.3 & $65.3 \pm 0.7$ & $32.4 \pm 0.5$ & $2.674 \pm 0.007$ & $0.818 \pm 0.007$ & 9.4 \\
\hline SG-15 & 180.7 & -15.1 & $69.1 \pm 0.3$ & $30.1 \pm 0.4$ & $2.683 \pm 0.003$ & $0.795 \pm 0.023$ & 11.2 \\
\hline SG-18 & 200.2 & -17.5 & $76.1 \pm 0.7$ & $23.7 \pm 0.4$ & $2.745 \pm 0.006$ & $0.764 \pm 0.042$ & 11.7 \\
\hline SG-21 & 218.7 & -20.6 & $88.5 \pm 1.0$ & $17.3 \pm 0.2$ & $2.815 \pm 0.003$ & $0.750 \pm 0.011$ & 17.1 \\
\hline SG-22 & 225.3 & -22.2 & $92.3 \pm 0.4$ & $15.2 \pm 0.4$ & $2.852 \pm 0.009$ & $0.767 \pm 0.056$ & 17.2 \\
\hline
\end{tabular}

of the FREZCHEM (version 15.1) with ice, mirabilite, gypsum, and hydrohalite the only solids enabled in the mineral database. The FREZCHEM code is frequently used to investigate geochemical reactions in the cryosphere. It is based on the Pitzer formalism of ionic interactions in concentrated electrolyte solutions and includes ion pairs $\left(\mathrm{CaCO}_{3}^{0}, \mathrm{MgCO}_{3}^{0}, \mathrm{MgOH}^{+}\right)$with high for- 
mation constants (He and Morse, 1993), while it also accounts for the $\mathrm{SO}_{4}^{2-}$ $\mathrm{HSO}_{4}^{-}$equilibrium (Marion and Grant, 1994; Marion and Farren, 1999). The code runs replicated the experimental starting solution compositions (i.e. prior to seeding) studied in the protocols outlined in section 2.4. Because the code is predominately designed to simulate mineral-solution equilibrium from precipitation, excess gypsum or hydrohalite were added to the FREZCHEM input files when the brine-gypsum and brine-hydrohalite equilibrium was simulated for undersaturated experimental brines. The derivation of $K_{\mathrm{sp} \text {,gypsum }}^{*}$ and $K_{\mathrm{sp} \text {,hydrohalite }}^{*}$ from the code output was based on that used for ikaite (Papadimitriou et al., 2013) and mirabilite (Butler et al., 2016b) solubilities in sea ice brines.

\subsection{First-year sea ice modelling}

The FREZCHEM code was also run to simulate freezing of Standard Seawater (Millero et al., 2008) in order to determine the mass of hydrohalite precipitate as a function of temperature between $-22.9^{\circ} \mathrm{C}$ and $-36.0^{\circ} \mathrm{C}$, i.e., the temperature field between the onset of hydrohalite precipitation and the seawater eutectic in the presence of gypsum and mirabilite. The fractional crystallisation pathway (section 1) was used for this computation, which does not allow further brine-mirabilite reaction during hydrohalite precipitation, and so, it reflected the hydrohalite solubility experiments carried out using protocol-3 (section 2.4). As will be shown, the FREZCHEM code accurately computes hydrohalite equilibria in sea ice brines (section 3.4), thus justifying its use here. The mass of hydrohalite precipitate extracted from the FREZCHEM output at $0.25{ }^{\circ} \mathrm{C}$ cooling steps was incorporated into a $1 \mathrm{D}$ numerical model of first-year sea ice (Cox and Weeks, 1988) as described for mirabilite in Butler et al. (2016b). The 1D model calculated the thickness and bulk $S_{\mathrm{A}}$ depth profile of the ice pack as it grows in autumn-winter, and accounts for brine drainage in permeable sea ice $\left(T>-5^{\circ} \mathrm{C}\right)$ and the effect of hydrohalite precipitation on brine salinity $\left(T<-22.9^{\circ} \mathrm{C}\right)$. The model was used to estimate the hydrohalite mass per unit mass of sea ice $(0.5 \mathrm{~cm}$ depth 
increments) at temperature $T\left[H_{i}(T)\right.$, in $\mathrm{g} \mathrm{kg}^{-1}$ sea ice $]$ after desalination by

$$
H_{i}(T)=H(T) \frac{S_{\mathrm{i}}}{S_{\mathrm{sw}}}
$$

where $H(T)$ is the hydrohalite mass at temperature $T$ that would precipitate from $1 \mathrm{~kg}$ of Standard Seawater $\left(S_{\mathrm{A}}=35.165 \mathrm{~g} \mathrm{~kg}^{-1}\right)$ based on the FREZCHEM model output, $S_{\mathrm{i}}$ is the bulk $S_{\mathrm{A}}$ of the ice as calculated by the $1 \mathrm{D}$ model, and $S_{\mathrm{sw}}$ is the $S_{\mathrm{A}}$ of Standard Seawater. The incorporation of hydrohalite precipitation dynamics into the sea ice model allowed evaluation of its temporal depth distribution in sea ice as the modelled ice pack grows throughout an Arctic winter.

\section{Results}

\subsection{Gypsum solubility and saturation state between 0.2 and $-22.2{ }^{\circ} \mathrm{C}$}

The positive $\Delta \mathrm{Ca}^{2+}$ values during protocol-1 and protocol-2 experiments (Table 3) indicate that the brine-gypsum equilibrium was attained by dissolution of the gypsum seed throughout the 0.2 to $-22.2{ }^{\circ} \mathrm{C}$ temperature range, and so the $p K_{\mathrm{sp} \text {,gypsum }}^{*}$ was determined from undersaturation. This becomes evident in $\Omega_{\text {gypsum }}$ remaining below 1 throughout this temperature range, approaching, but not exceeding, saturation $(\Omega=1)$ only at $-6.8^{\circ} \mathrm{C}$ (Figure 2 ; Table 3$)$. The $p K_{\text {sp,gypsum }}^{*}$ increased from 2.878 to 2.900 between 0.2 and $-1.8^{\circ} \mathrm{C}$, which represents a slight reduction in gypsum solubility with decreasing temperature at constant salinity in seawater (Figure 1; Table 3). Between -1.8 and $-6.0{ }^{\circ} \mathrm{C}$, the $p K_{\mathrm{sp} \text {,gypsum }}^{*}$ decreased from 2.900 to 2.587 with decreasing temperature in brines representative of conservative physical solute concentration. The $p K_{\mathrm{sp} \text {,gypsum }}^{*}$ was relatively stable $(2.591 \pm 0.004$, $n=5$ ) between -6.8 and $-10.1{ }^{\circ} \mathrm{C}$, and then increased measurably and monotonically to 2.852 between -10.1 and $-22.2^{\circ} \mathrm{C}$ in conditions of decreasing temperature, increasing ionic strength, and increasingly reduced $\mathrm{SO}_{4}^{2-}$ via mirabilite precipitation from the brine before and during the gypsum 


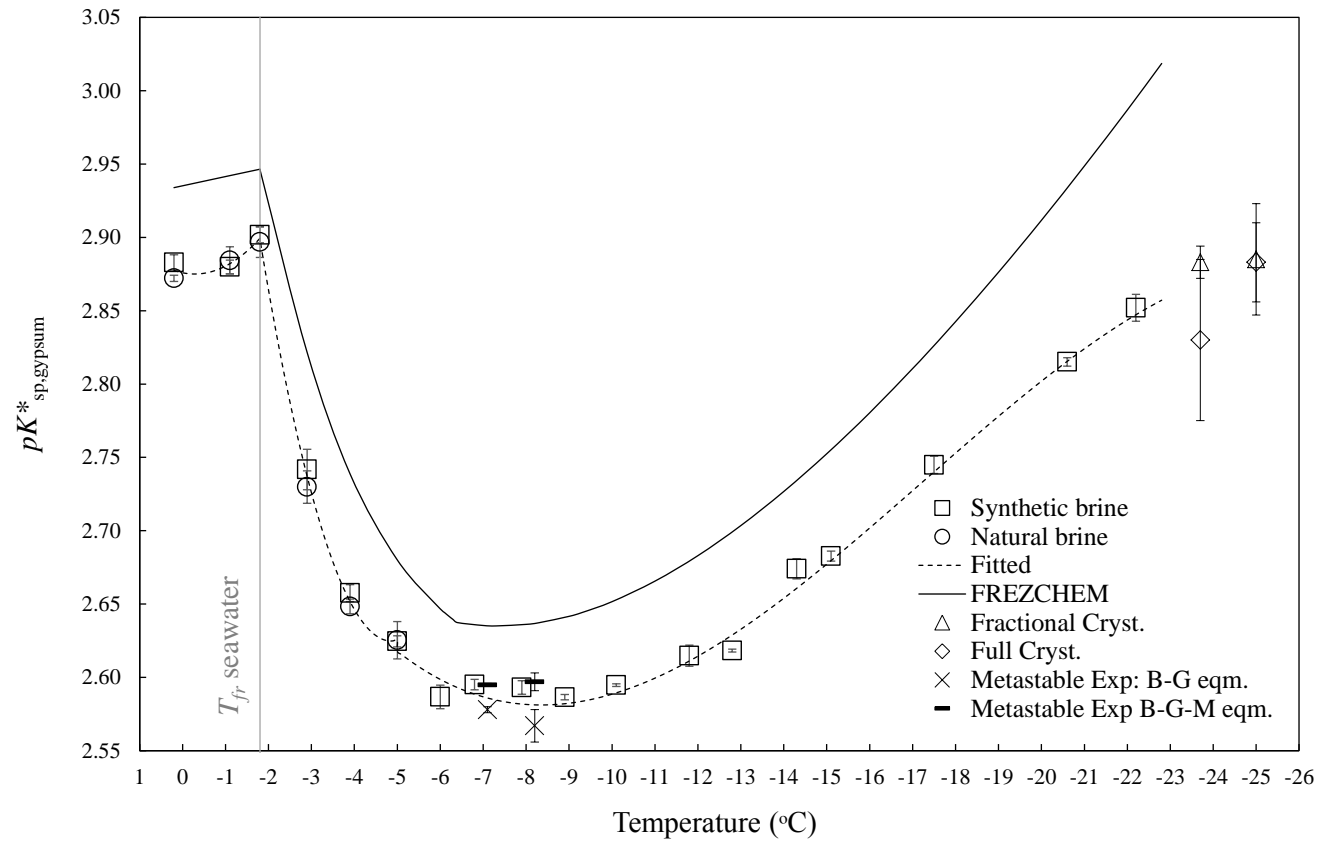

Figure 1: Measured $p K_{\mathrm{sp}, \text { gypsum }}^{*}$ in equilibrium sea ice brines plotted alongside output from the FREZCHEM model both for the seawater $\left(0\right.$ to $\left.-1.8^{\circ} \mathrm{C}\right)$, ice-brine $\left(-1.8\right.$ to $\left.-6.4^{\circ} \mathrm{C}\right)$, and ice-brine-mirabilite $\left(-6.4\right.$ to $\left.-22.2{ }^{\circ} \mathrm{C}\right)$ equilibrium systems. Also plotted are the $p K_{\mathrm{sp}, \mathrm{gypsum}}^{*}$ measurements in full and equilibrium crystallisation conditions at -23.7 and $-25.0{ }^{\circ} \mathrm{C}$ (see sections 2.4 and 3.3). The vertical line at $-1.8{ }^{\circ} \mathrm{C}$ marks the point of which the solubility product begins to become affected by coupled changes in salinity and temperature as a result of freezing. The fitted line is based only on measurements from synthetic and natural brines (square and circle markers) between 0.2 and $-22.2{ }^{\circ} \mathrm{C}$. B = Brine, $\mathrm{G}=$ Gypsum, $\mathrm{M}=$ Mirabilite.

solubility experiments (Figure 1; Table 3). Mirabilite seed was not present during the gypsum solubility experiments in this temperature range, but the initial brine equilibrated with mirabilite before the gypsum solubility experiments (protocol-2) and, also, during the experiments. The $\mathrm{SO}_{4}^{2-}$ addition to the mirabilite-equilibrated brine via gypsum seed dissolution resulted in mirabilite supersaturation and further mirabilite precipitation from this brine. Mirabilite as a result of this gypsum dissolution reaction was identified by XRPD analysis of the solids recovered at the end of these experiments (section 2.1. The $K_{\mathrm{sp}, \text { gypsum }}^{*}$ between -6.8 and $-22.2{ }^{\circ} \mathrm{C}$ therefore represents 
the brine-mirabilite-gypsum equilibrium.

\subsection{Gypsum dynamics in conditions of metastable mirabilite supersaturation}

In the experiments carried out under metastable conditions of mirabilite supersaturation at -7.1 and $-8.2{ }^{\circ} \mathrm{C}$, the initial brines had a composition equivalent to that resulting from physical solute concentration at ice-brine equilibrium. Mirabilite would almost certainly not precipitate by homogeneous nucleation in these conditions, and so, these brines had $\Omega_{\text {mirabilite }}=$ 1.252 and 1.717 at -7.1 and $-8.2{ }^{\circ} \mathrm{C}$, respectively, calculated from the $\Omega_{\text {mirabilite }}-T$ relationship in Butler et al. (2016b). Seeding these brines with gypsum resulted in a decrease in $\mathrm{Ca}^{2+}$ and $\mathrm{SO}_{4}^{2-}$, with a $\Delta \mathrm{Ca}^{2+}: \Delta \mathrm{SO}_{4}^{2-}=$ $0.90 \pm 0.05$ (Table 4), indicating gypsum precipitation. Based on the $p K_{\text {gypsum }}^{*}$ determined at the brine-gypsum equilibrium of these experiments (Table 4), the saturation state of the initial ice-brine equilibrium condition was $\Omega_{\text {gypsum }}=$ 1.173 at $-7.1{ }^{\circ} \mathrm{C}$ and 1.379 at $-8.2{ }^{\circ} \mathrm{C}$. The measured $\Delta \mathrm{Ca}^{2+}$ indicates that the amount of gypsum precipitate at brine-gypsum equilibrium was $3.8 \mathrm{mmol}$ $\mathrm{kg}^{-1}$ at $-7.1^{\circ} \mathrm{C}$ and $7.5 \mathrm{mmol} \mathrm{kg}^{-1}$ at $-8.2{ }^{\circ} \mathrm{C}$.

The subsequent seeding of the brine-gypsum equilibrium solutions with mirabilite in the presence of the gypsum seed/precipitate resulted in an increase in $\mathrm{Ca}^{2+}$ and further reduction of $\mathrm{SO}_{4}^{2-}$ (Table 4), implying concurrent gypsum dissolution and mirabilite precipitation by heterogeneous nucleation, respectively. This suggests that, despite the $\mathrm{SO}_{4}^{2-}$ removal from solution as gypsum, the brines at brine-gypsum equilibrium remained in a metastable supersaturated state with respect to mirabilite. It is also apparent that the consequent $\mathrm{SO}_{4}^{2-}$ removal to mirabilite resulted in $\Omega_{\text {gypsum }}<1$, facilitating gypsum dissolution. Based on the $\mathrm{Ca}^{2+}$ difference between the brinegypsum and brine-gypsum-mirabilite equilibrium (Table 4), the amount of gypsum that dissolved in the presence of mirabilite seed was 4.7 and 9.1 mmol kg ${ }^{-1}$ at -7.1 and $-8.2{ }^{\circ} \mathrm{C}$, respectively. This amount of gypsum dissolution exceeds the amount of gypsum precipitation at sustained metastable mirabilite supersaturation and brine-gypsum equilibrium (computed in the 


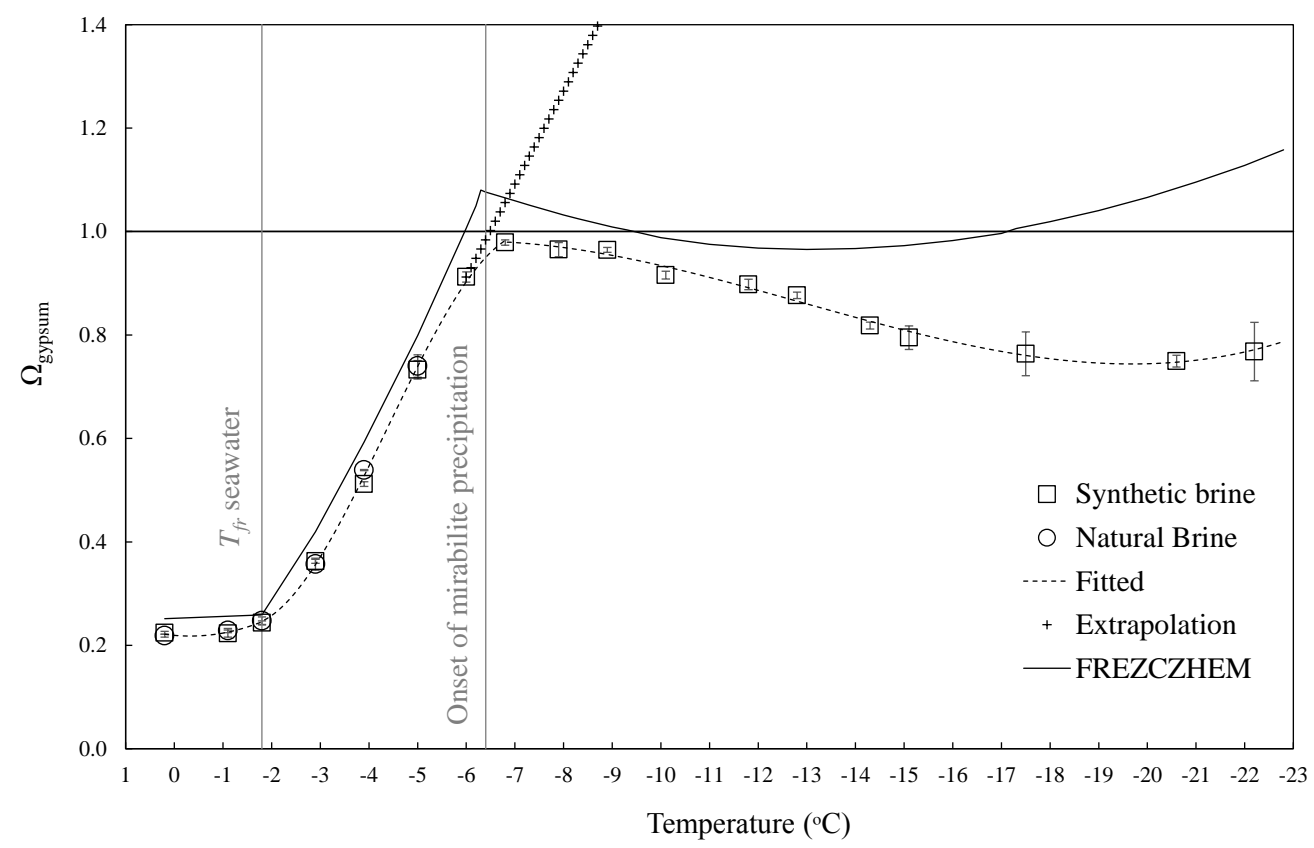

Figure 2: The measured $\Omega_{\text {gypsum }}$ in equilibrium sea ice brines between 0.2 and $-22.2{ }^{\circ} \mathrm{C}$ plotted alongside the output from the FREZCHEM model. The vertical line at $-1.8{ }^{\circ} \mathrm{C}$ marks the point of which the saturation state begins to become affected by coupled changes in salinity and temperature as a result of freezing, while that at $-6.4{ }^{\circ} \mathrm{C}$ marks the onset of mirabilite precipitation. The horizontal line at $\Omega_{\text {gypsum }}=1$ is used to highlight the transition between undersaturation $\left(\Omega_{\text {gypsum }}<1\right)$ and supersaturation $\left(\Omega_{\text {gypsum }}>1\right)$.

previous paragraph). This then indicates that gypsum should be unstable once mirabilite begins to form. The $p K_{\mathrm{sp} \text {,gypsum }}^{*}$ at brine-mirabilite-gypsum equilibrium obtained from these experiments was in close agreement with the $p K_{\mathrm{sp} \text {,gypsum }}^{*}-T$ relationship outlined in section 3.1 (Figure 1; Tables 3 and 4). This indicates that identical chemical equilibrium conditions can be attained independently of the order of mineral seeding/nucleation.

\subsection{Gypsum solubility in the fractional and full crystallisation pathways}

The brines used for the gypsum solubility measurements in conditions representative of fractional and full crystallisation pathways at -23.7 and $-25.0{ }^{\circ} \mathrm{C}$ were extracted from the ice-hydrohalite aggregate in protocol-3 
Table 4: Equilibrium measurements of $\mathrm{Ca}^{2+}$ and $\mathrm{SO}_{4}^{2-}$ concentrations from experiments that investigated gypsum solubility in conditions of metastable mirabilite supersaturation at -7.1 and $-8.2{ }^{\circ} \mathrm{C} . *$ denotes solutions that were supersaturated with respect to mirabilite at the point of measurement. Tabulated errors are calculated as the standard deviation of measurements from triplicate experiments.

\begin{tabular}{lcccc}
\hline & $T$ & $\mathrm{Ca}^{2+}$ & $\mathrm{SO}_{4}^{2-}$ & \\
\cline { 3 - 4 } System & ${ }^{\circ} \mathrm{C}$ & \multicolumn{2}{c}{$\mathrm{mmol} \mathrm{kg}_{\text {sol }}^{-1}$} & $p K_{\text {sp,gypsum }}^{*}$ \\
\hline Ice-brine* & -7.1 & $33.8 \pm 0.1$ & $91.9 \pm 0.6$ & \\
Brine-gypsum* & -7.1 & $30.0 \pm 0.1$ & $88.0 \pm 0.6$ & $2.578 \pm 0.002$ \\
Brine-gypsum-mirabilite & -7.1 & $34.7 \pm 0.1$ & $73.2 \pm 0.2$ & $2.595 \pm 0.001$ \\
& & & & \\
Ice-brine* & -8.2 & $37.1 \pm 0.4$ & $100.7 \pm 0.2$ & \\
Brine-gypsum* & -8.2 & $29.6 \pm 0.5$ & $91.6 \pm 1.0$ & $2.567 \pm 0.011$ \\
Brine-gypsum-mirabilite & -8.2 & $38.7 \pm 0.4$ & $65.3 \pm 0.3$ & $2.597 \pm 0.006$ \\
\hline
\end{tabular}

experiments (section 2.4). These brines were at equilibrium with ice and hydrohalite but supersaturated with respect to gypsum because, when incubated only with gypsum seed (representative of the fractional crystallisation pathway), a negative $\Delta \mathrm{Ca}^{2+}$ was observed, implying 6.8 and $9.3 \mathrm{mmol} \mathrm{kg}{ }^{-1}$ of gypsum precipitate at -23.7 and $-25.0{ }^{\circ} \mathrm{C}$, respectively (Table 5). This corresponds to $\Omega_{\text {gypsum }}=1.064$ and 1.069 in the brines of the ice-hydrohalite aggregate at -23.7 and $-25.0^{\circ} \mathrm{C}$, respectively (Table 5). When these brines were seeded with both gypsum and mirabilite (representative of the full crystallisation pathway), the $\Delta \mathrm{Ca}^{2+}$ was more negative and the $\Delta \mathrm{SO}_{4}^{2-}$ less so than in the absence of mirabilite in the fractional crystallisation pathway at both temperatures (Table 5). The $\Delta \mathrm{Ca}^{2+}$ in these experiments is equivalent

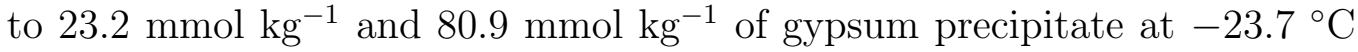
(corresponding to $\Omega_{\text {gypsum }}=1.257$ in the initial brine) and $-25.0{ }^{\circ} \mathrm{C}$ (corresponding to $\Omega_{\text {gypsum }}=2.276$ in the initial brine), respectively (Table 5). Collectively, these observations indicate enhanced gypsum precipitation in the presence of mirabilite, with the additional source of $\mathrm{SO}_{4}^{2-}$ provided by mirabilite dissolution.

The $p K_{\text {gypsum }}^{*}$ determined at brine-hydrohalite-gypsum equilibrium (frac- 
tional crystallisation pathway) was in close agreement with the values determined at brine-mirabilite-hydrohalite-gypsum equilibrium (full crystallisation pathway) at $-25.0^{\circ} \mathrm{C}$ and within experimental uncertainty at $-23.7^{\circ} \mathrm{C}$, despite differing equilibrium brine composition and inter-ionic ratios of $\mathrm{Ca}^{2+}$ and $\mathrm{SO}_{4}^{2-}$ (Table 5; Figure 1). This suggests that, within experimental error at the two coldest temperatures of this investigation, the $p K_{\text {gypsum }}^{*}$ is not measurably influenced by differences in the equilibrium ionic composition of the brine resulting from the fractional and full crystallisation pathways.

Table 5: Equilibrium measurements of gypsum solubility at -23.7 and $-25.0{ }^{\circ} \mathrm{C}$ in experiments considered representative of fractional and full crystallisation. The $\Omega_{\text {gypsum }}$ values presented here were based exclusively on the $\Delta \mathrm{Ca}^{2+}$, since the $\mathrm{SO}_{4}^{2-}$ is affected by mirabilite dissolution. $\Delta \mathrm{Ca}^{2+}=\mathrm{Ca}_{\text {eqm }}^{2+}-\mathrm{Ca}_{\text {initial }}^{2+} . \Delta \mathrm{SO}_{4}^{2-}=\mathrm{SO}_{4 \text { eqm }}^{2-}-\mathrm{SO}_{4}^{2-}$ initial. Tabulated errors are calculated as the standard deviation of measurements from triplicate experiments.

\begin{tabular}{|c|c|c|c|c|c|c|c|}
\hline \multirow[b]{2}{*}{ Type } & \multirow{2}{*}{$\begin{array}{c}\mathrm{T} \\
{ }^{\circ} \mathrm{C}\end{array}$} & $\mathrm{Ca}^{2+}$ & $\mathrm{SO}_{4}^{2-}$ & \multirow[b]{2}{*}{$p K_{\mathrm{sp}, \mathrm{gypsum}}^{*}$} & \multirow{3}{*}{$\frac{\Omega_{\text {gypsum }}}{1.064 \pm 0.027}$} & \multicolumn{2}{|c|}{$\Delta \mathrm{Ca}^{2+} \quad \Delta \mathrm{SO}_{4}^{2-}$} \\
\hline & & \multicolumn{2}{|c|}{$\mathrm{mmol} \mathrm{kg}_{\text {sol }}^{-1}$} & & & $\mathrm{mmo}$ & $\mathrm{kg}_{\text {sol }}^{-1}$ \\
\hline Fractional & -23.7 & $107.0 \pm 1.0$ & $12.2 \pm 0.4$ & $2.883 \pm 0.011$ & & -6.8 & -6.6 \\
\hline Full & -23.7 & & $16.5 \pm$ & & & -23.2 & -2.4 \\
\hline & -25.0 & $135.3 \pm 0.4$ & $9.7 \pm$ & & & -9.3 & -13.3 \\
\hline Full & -25.0 & $63.7 \pm 3.8$ & $20.6 \pm 2.1$ & $2.883 \pm 0.027$ & $2.276 \pm 0.139$ & -80.9 & -2.1 \\
\hline
\end{tabular}

\subsection{Hydrohalite solubility and saturation state}

The brine-hydrohalite equilibrium was attained by dissolution between -14.3 and $-22.0^{\circ} \mathrm{C}$ in protocol-2 experiments (section 2.4), as evidenced by positive $\Delta \mathrm{Cl}^{-}$(Table 6). In this temperature range, the $p K_{\mathrm{sp} \text {,hydrohalite }}^{*}$ (Figure 3) and $\Omega_{\text {hydrohalite }}$ (Figure 4) increased from -1.175 to -1.107 and from 0.465 to 0.953 (Table 6), respectively, indicating a decrease in hydrohalite solubility with decreasing temperature at brine-hydrohalite equilibrium. During the protocol-3 experiments (section 2.4) at -23.7 and $-25.0^{\circ} \mathrm{C}$, the icebrine-hydrohalite equilibrium was attained by precipitation as evidenced by negative $\Delta \mathrm{Cl}^{-}$values (estimated using FREZCHEM; see below and Table 6). The $p K_{\mathrm{sp} \text {,hydrohalite }}^{*}$ increased sharply to -0.976 at $-25.0{ }^{\circ} \mathrm{C}$, representing a 
dramatic decrease in hydrohalite solubility at $T \leqslant-22.9{ }^{\circ} \mathrm{C}$ (Figure 3) in the fractional crystallisation pathway.

Because it was not possible to determine $\Omega_{\text {hydrohalite }}$ experimentally at -23.7 and $-25.0^{\circ} \mathrm{C}$, the FREZCHEM code was used to compute the solution composition at ice-brine-mirabilite equilibrium at these temperatures by excluding hydrohalite and gypsum from the mineral database. At $T \leqslant$ $-22.9^{\circ} \mathrm{C}$, the $\Omega_{\text {hydrohalite }}$ increased steeply to 3.848 at $-25.0^{\circ} \mathrm{C}$ (Figure 4 ). Because the $p K_{\mathrm{sp} \text {,hydrohalite }}^{*}$ from the experiments between -14.3 and $-25.0^{\circ} \mathrm{C}$ was in excellent agreement with that of the FREZCHEM model (Figure 3), the experimental values were combined with the FREZCHEM model output to derive the $p K_{\mathrm{sp}, \text { hydrohalite }}^{*}-T$ relationship (eq. 1 ; Table 2 ).

\section{Discussion}

This section will associate the laboratory measurements of gypsum and hydrohalite solubilities to their dynamics within the natural sea ice environment. Discussing hydrohalite dynamics in this context highlights its role within the sea ice system as a mediator of physical sea ice properties, and its contribution to geochemical changes that add to physiological challenges imposed upon sympagic biota. Discussing gypsum dynamics in this context aids in elucidating the conditions in which it can precipitate and persist in sea ice, and allows evaluation of its potential as a marine deposit.

\subsection{Gypsum solubility in seawater and sea ice brines between 0.2 and $-22.2^{\circ} \mathrm{C}$}

The consistency in $p K_{\mathrm{sp} \text {,gypsum }}^{*}$ determined in both natural and synthetic sea ice brines between 0.2 and $-5.0{ }^{\circ} \mathrm{C}$ (Figure 1 ; Table 3) indicates that, as with mirabilite solubility (Butler et al., 2016b), gypsum solubility is unaffected by parameters such as $\mathrm{pH}$, carbonate and borate alkalinity, and trace metals within the measurement uncertainty. By considering solutions either at equilibrium, or supersaturated, or undersaturated with respect to mirabilite, gypsum solubility was measured mostly via dissolution, with measurements via precipitation possible on a few occasions, in a range of scenarios 
Table 6: The absolute salinity $\left(S_{\mathrm{A}}\right)$ of incubated brines prior to seeding with hydrohalite (see footnote for exceptions), incubation temperature at point of sampling, $\mathrm{Na}^{+}$and $\mathrm{Cl}^{-}$ concentrations from each of the bottle incubations at equilibrium, the resulting measured $p K_{\mathrm{sp} \text {,hydrohalite }}^{*}$ and $\Omega_{\mathrm{hydrohalite}}$, and the change in $\mathrm{Cl}^{-}$observed over the course of each experiment, included as a measure of reaction direction $\left(\Delta \mathrm{Cl}^{-}=\mathrm{Cl}_{\text {eqm }}^{-}-\mathrm{Cl}_{\text {initial }}^{-}\right)$. All data above $-22.9^{\circ} \mathrm{C}$ are derived from dissolution of hydrohalite in solutions extracted from an ice-brine-mirabilite equilibrium system (see protocol-2, section 2.4). $\mathrm{D}=$ dissolution, $\mathrm{P}=$ precipitation. Tabulated errors are calculated as the standard deviation of measurements from triplicate experiments.

\begin{tabular}{|c|c|c|c|c|c|c|c|c|}
\hline \multirow[b]{2}{*}{ Exp. \# } & \multirow[b]{2}{*}{ Reaction } & \multirow{2}{*}{$\begin{array}{c}S_{\mathrm{A}} \\
\mathrm{g} \mathrm{kg}_{\text {sol }}^{-1}\end{array}$} & \multirow{2}{*}{$\begin{array}{l}\mathrm{T} \\
{ }^{\circ} \mathrm{C}\end{array}$} & $\mathrm{Na}^{+}$ & $\mathrm{Cl}^{-}$ & \multirow[b]{2}{*}{$p K_{\mathrm{sp}, \text { hydrohalite }}^{*}$} & \multirow[b]{2}{*}{$\Omega_{\text {hydrohalite }}$} & \multirow{2}{*}{$\begin{array}{c}\Delta \mathrm{Cl}^{-} \\
\mathrm{mmol} \mathrm{kg}-1\end{array}$} \\
\hline & & & & \multicolumn{2}{|c|}{$\mathrm{mmol} \mathrm{kg}_{\text {sol }}^{-1}$} & & & \\
\hline H-14 & $\mathrm{D}$ & $173.8^{\mathrm{a}}$ & -14.3 & $3596 \pm 26$ & $4164 \pm 5$ & $-1.175 \pm 0.003$ & $0.465 \pm 0.003$ & 1170 \\
\hline H-15 & D & $180.7^{\mathrm{a}}$ & -15.1 & $3591 \pm 18$ & $4159 \pm 8$ & $-1.174 \pm 0.002$ & $0.508 \pm 0.001$ & 1022 \\
\hline H-16 & D & $187.8^{\mathrm{a}}$ & -15.9 & $3503 \pm 20$ & $4130 \pm 3$ & $-1.160 \pm 0.003$ & $0.568 \pm 0.004$ & 857 \\
\hline $\mathrm{H}-17$ & $\mathrm{D}$ & $200.2^{\mathrm{a}}$ & -17.5 & $3403 \pm 33$ & $4120 \pm 12$ & $-1.147 \pm 0.003$ & $0.672 \pm 0.006$ & 632 \\
\hline H-18 & $\mathrm{D}$ & $201.3^{\mathrm{a}}$ & -18.0 & $3398 \pm 35$ & $4102 \pm 11$ & $-1.144 \pm 0.004$ & $0.693 \pm 0.004$ & 579 \\
\hline $\mathrm{H}-21$ & $\mathrm{D}$ & $218.7^{\mathrm{a}}$ & -20.6 & $3181 \pm 28$ & $4053 \pm 4$ & $-1.110 \pm 0.002$ & $0.886 \pm 0.003$ & 189 \\
\hline H-22 & $\mathrm{D}$ & $225.9^{\mathrm{a}}$ & -22.0 & $3173 \pm 40$ & $4031 \pm 7$ & $-1.107 \pm 0.003$ & $0.953 \pm 0.001$ & 87 \\
\hline H-24 & $\mathrm{P}$ & $225.3^{\mathrm{a}, \mathrm{b}}$ & -23.7 & $2720 \pm 36$ & $4094 \pm 8$ & $-1.047 \pm 0.004$ & $2.037 \pm 0.001^{\mathrm{c}}$ & $-1359^{\mathrm{c}}$ \\
\hline $\mathrm{H}-25$ & $\mathrm{P}$ & $225.3^{\mathrm{a}, \mathrm{b}}$ & -25.0 & $2274 \pm 22$ & $4158 \pm 18$ & $-0.976 \pm 0.005$ & $3.848 \pm 0.011^{\mathrm{c}}$ & $-2747^{\mathrm{c}}$ \\
\hline
\end{tabular}

${ }^{\text {a }} S_{\mathrm{A}}$ measured at brine-ice-mirabilite equilibrium.

b Brine further cooled to target temperature, initiating ice and hydrohalite precipitation.

c Estimated from brine-mirabilite equilibrium using FREZCHEM.

relevant to sea ice. It is noted that these incubations do not account for the effect of ikaite precipitation on the availability of $\mathrm{Ca}^{2+}$ within the sea ice brine system, but this effect is predicted to be relatively minor (Butler et al., 2016a).

The current measurements of the stoichiometric solubility product of gypsum (Figure 1) indicated that seawater and the ice-brine and ice-brinemirabilite equilibrium systems between 0.2 and $-22.2^{\circ} \mathrm{C}$ were all undersaturated with respect to gypsum, as reflected in the $\Omega_{\text {gypsum }}$ remaining below 1 (Figure 2). Exception to this trend is a narrow temperature range of metastable mirabilite supersaturation between $-6.4{ }^{\circ} \mathrm{C}$ and $-8.2{ }^{\circ} \mathrm{C}$ that concurs with gypsum supersaturation, which can lead to gypsum precipitation (see section 4.2 for further discussion).

The equilibrium $\mathrm{Ca}^{2+}$ as a function of temperature between -6.4 and 


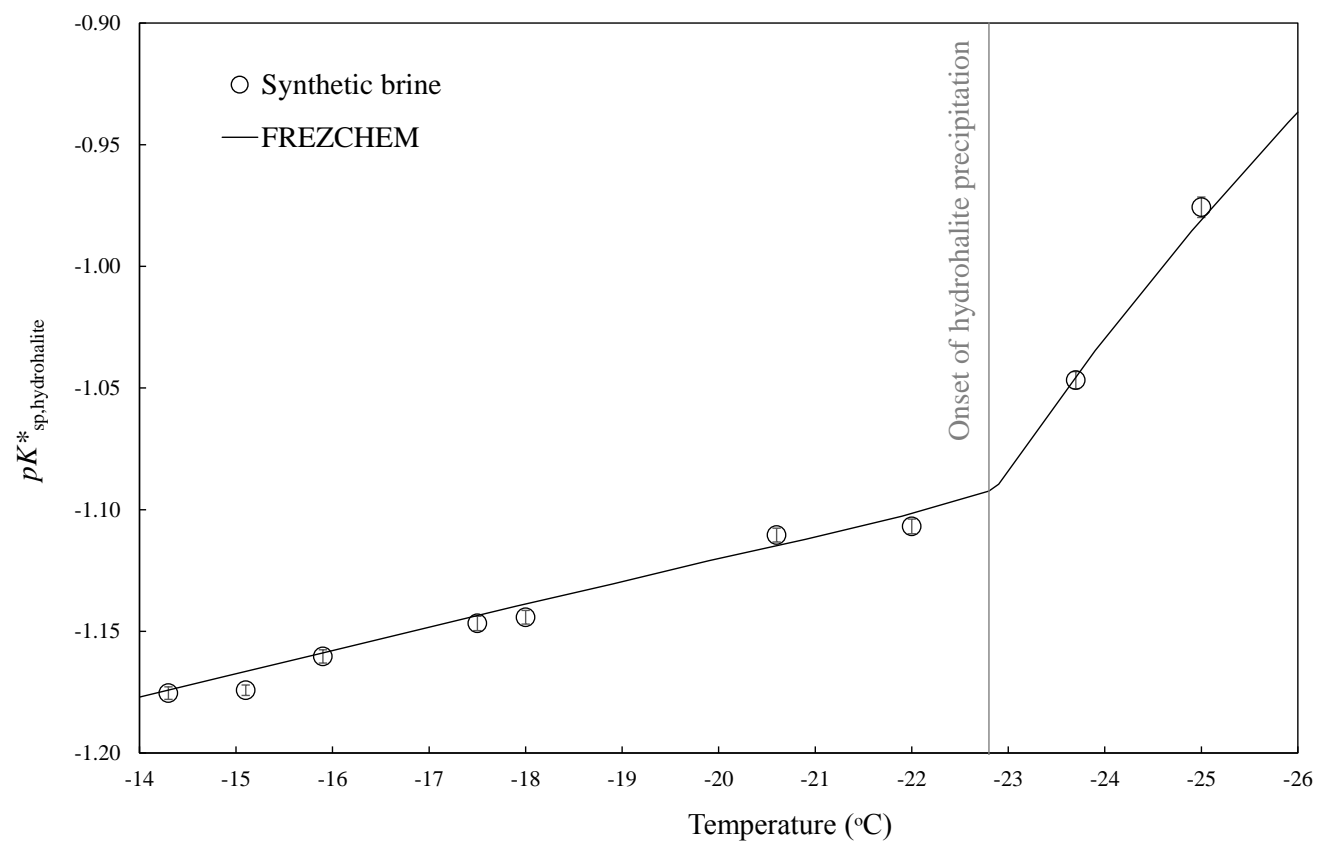

Figure 3: Measured $p K_{\mathrm{sp}, \text { hydrohalite }}^{*}$ in equilibrium sea ice brines plotted alongside the output from the FREZCHEM model. The vertical line at $-22.9{ }^{\circ} \mathrm{C}$ marks the point of which the solubility product begins to become affected by the precipitation of hydrohalite. All data above $-22.9{ }^{\circ} \mathrm{C}$ are derived from dissolution of hydrohalite seed in solutions extracted from an ice-brine-mirabilite equilibrium system (see protocol-2, section 2.4).

$-22.2{ }^{\circ} \mathrm{C}$ (Figure 5, top panel) reflects the increase by both physical concentration of a cooling ice-brine system and the dissolution of the gypsum seed in the current experiments, the latter reaction leading to higher $\mathrm{Ca}^{2+}$ than in conservatively concentrated seawater-derived brine at each experimental temperature. In contrast, the decrease in equilibrium $\mathrm{SO}_{4}^{2-}$ between -6.4 and $-22.2{ }^{\circ} \mathrm{C}$ reflects the imbalance between the processes that increase $\mathrm{SO}_{4}^{2-}$, i.e., the physical concentration of the brine during cooling of the system and the dissolution of the gypsum seed during the experiments, and the removal of $\mathrm{SO}_{4}^{2-}$ from the brine before and during the solubility experiments via mirabilite precipitation (Figure 5, bottom panel). The $\mathrm{Ca}^{2+}$ at brine-mirabilite-gypsum equilibrium predicted by the FREZCHEM code 


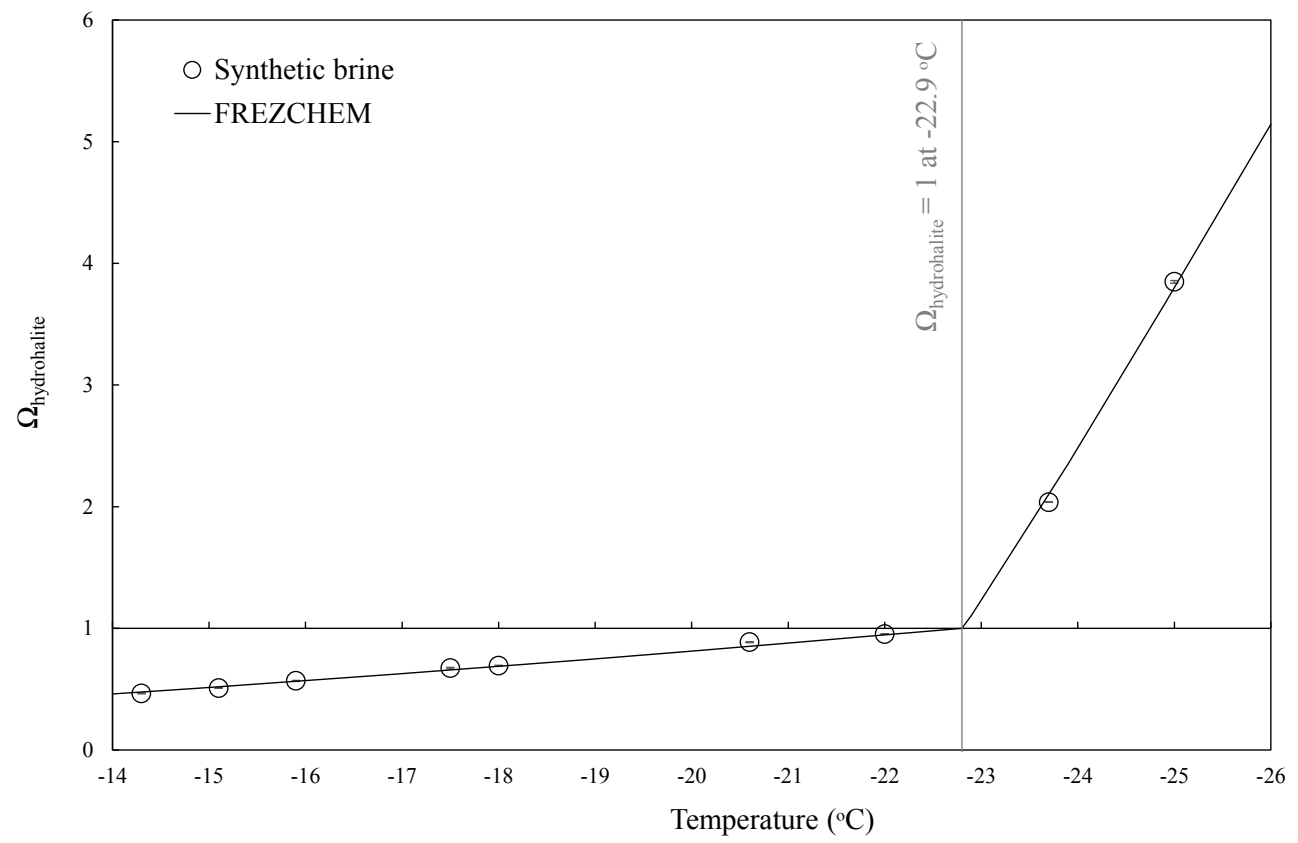

Figure 4: Measured $\Omega_{\text {hydrohalite }}$ in equilibrium sea ice brines plotted alongside the output from the FREZCHEM model. The vertical line at $-22.9{ }^{\circ} \mathrm{C}$ marks the point of which the saturation state begins to become affected by precipitation of hydrohalite. The horizontal line at $\Omega_{\text {hydrohalite }}=1$ is used to highlight the transition between undersaturation $\left(\Omega_{\text {hydrohalite }}<1\right)$ and supersaturation $\left(\Omega_{\text {hydrohalite }}>1\right)$. All data above $-22.9{ }^{\circ} \mathrm{C}$ are derived from dissolution of hydrohalite in solutions extracted from an ice-brine-mirabilite equilibrium system (see protocol-2, section 2.4).

showed increasing deviation from the measured equilibrium concentrations with decreasing temperature below $-10{ }^{\circ} \mathrm{C}$ (Figure 5, top panel). This deviation was not observed between the measured and modelled equilibrium $\mathrm{SO}_{4}^{2-}$ (Figure 5, bottom panel). The close agreement between code output and observations as regards $\mathrm{SO}_{4}^{2-}$ reflects the mirabilite equilibrium $\left(\Omega_{\text {mirabilite }}=1\right)$ via precipitation before and during the brine incubation with gypsum, the latter fuelled by the excess $\mathrm{SO}_{4}^{2-}$ released into the brine via dissolution of the gypsum seed and supported by synchrotron XRPD (sections 2.1 and 3.1).

Direct comparison of the measured $p K_{\mathrm{sp}, \mathrm{gypsum}}^{*}$ with values derived from the FREZCHEM output (section 2.5; Figure 1) shows that the FREZCHEM- 
derived values follow the same trend with temperature as the experimentally determined values, but the code overestimates the $p K_{\mathrm{sp}, \text { gypsum }}^{*}$ by $0.069 \pm 0.024$ throughout the investigated temperature range. Between 0.2 and $-10.1^{\circ} \mathrm{C}$, FREZCHEM underestimated the equilibrium $\mathrm{Ca}^{2+}$ and $\mathrm{SO}_{4}^{2-}$ by $2.03 \pm 0.98$ and $3.14 \pm 3.05 \mathrm{mmol} \mathrm{kg}^{-1}$, respectively (Figure 5). As mentioned above, between -10.1 and $-22.2{ }^{\circ} \mathrm{C}$, the FREZCHEM computation of the equilibrium $\mathrm{SO}_{4}^{2-}$ was increasingly consistent with measurements, with deviations decreasing from 5.82 to $0.15 \mathrm{mmol} \mathrm{kg}^{-1}$, as would be expected from the reliable representation of measured mirabilite equilibria by the thermodynamic database of the code (Butler et al., 2016b). In contrast, the underestimation of equilibrium $\mathrm{Ca}^{2+}$ by the code increased from 1.54 to $25.33 \mathrm{mmol} \mathrm{\textrm {kg } ^ { - 1 }}$ between -10.1 and $-22.2{ }^{\circ} \mathrm{C}$. This discrepancy was also seen in the $\Omega_{\text {gypsum }}$ (Figure 2), with the FREZCHEM predictions consistently exceeding those based on the experimental values. Between 0.2 and $-22.2{ }^{\circ} \mathrm{C}$, the current experiments indicate that gypsum would not exceed saturation in the presence of mirabilite in the sea ice brines but the FREZCHEM code shows two regions of gypsum supersaturation: first between -6.4 and $-9.3{ }^{\circ} \mathrm{C}$, and secondly at temperatures $\leqslant-17.3{ }^{\circ} \mathrm{C}$ (Figure 2).

Compared to its reliable computation of mirabilite (Butler et al., 2016b) and hydrohalite (Figures 3 and 4) dynamics in sea ice brines, the thermodynamic database of the FREZCHEM code yields gypsum dynamics in sea ice brines inconsistent with the dynamics determined here. The inconsistency is moreover particularly related to the modelled equilibrium $\mathrm{Ca}^{2+}$ between -10 and $-22.8^{\circ} \mathrm{C}$ (Figure 5). To predict gypsum solubility in the sea ice brines presented here, FREZCHEM parameters have to be extrapolated into an experimentally unknown region since the majority of relevant experimental data has a minimum temperature of $0{ }^{\circ} \mathrm{C}$ (Marion and Farren, 1997; Marion and Kargel, 2008; Raju and Atkinson, 1990; Marion et al., 2016). Such extrapolation is regularly applied at below-zero temperatures, and targeted experiments would help improve on the currently observed discrepancies with 
respect to gypsum solubility at these temperatures.

\subsection{Gypsum dynamics in metastable mirabilite supersaturation}

The degree of gypsum supersaturation observed in brines that sustained metastable supersaturation with respect to mirabilite $\left(\Omega_{\text {gypsum }}=1.171\right.$ at $-7.1^{\circ} \mathrm{C}$, and $\Omega_{\text {gypsum }}=1.358$ at $-8.2^{\circ} \mathrm{C}$ ) would be predicted by extrapolating the $\Omega_{\text {gypsum }}-T$ relationship observed at ice-brine equilibrium between -1.8 and $-6.0^{\circ} \mathrm{C}$ (Table 2 , row 5 ) into this temperature region with commensurate physical concentration of the brine (Figure 2, cross markers). Thus, gypsum precipitation could occur in sea ice at temperatures below $-7{ }^{\circ} \mathrm{C}$ if nucleation and crystal growth conditions are more favourable for this phase than for mirabilite. Even with gypsum precipitation under these conditions, mirabilite will remain supersaturated. The further the temperature decreases below $\sim-7 .{ }^{\circ} \mathrm{C}$, the greater the tendency for mirabilite to precipitate by homogeneous nucleation because its solubility in brines decreases sharply with decreasing temperature (Butler et al., 2016b) while that of gypsum is essentially unchanging $\left(p K_{\text {sp,gypsum }}^{*}=2.59\right)$ between -6 and $-10{ }^{\circ} \mathrm{C}$ (Figure 1). Subsequent mirabilite nucleation and precipitation in this temperature range will destabilize the gypsum completely. Therefore, over the $-6.4{ }^{\circ} \mathrm{C}$ to $-22.2{ }^{\circ} \mathrm{C}$ temperature range, mirabilite precipitation will dominate the compositional changes in the brine, with $92 \%$ of $\mathrm{SO}_{4}^{2-}$ removed from the brine as mirabilite by $-20.6{ }^{\circ} \mathrm{C}$ (Butler et al., 2016b).

Collectively the current results do not support the results of Gitterman (1937), who proposed gypsum to precipitate from synthetic seawater-derived brines below approximately $-15^{\circ} \mathrm{C}$. We instead propose that favourable conditions for gypsum precipitation in sea ice between -7 and $-22{ }^{\circ} \mathrm{C}$ are entirely dependent on the occurrence of metastable mirabilite supersaturation conditions, which are increasingly unlikely as the temperature decreases within this range. The sea ice brine system will return to the ice-brinemirabilite equilibrium and become undersaturated with respect to gypsum (Figure 2) once mirabilite authigenesis occurs. If gypsum precipitation oc- 
curs via this mechanism in natural sea ice, its presence is therefore expected to be transient in the presence of mirabilite.

\subsection{Fractional and full crystallisation pathways at -23.7 and $-25.0{ }^{\circ} \mathrm{C}$}

The more recent proposal for enhanced gypsum precipitation below $-22.9^{\circ} \mathrm{C}$ (Marion et al., 1999) is relevant to the temperature region of hydrohalite precipitation, ice formation, and significant reduction in brine volume (Richardson, 1976; Butler and Kennedy, 2015), with consequent substantial shifts in solution composition and inter-ionic ratios, particularly with respect to $\mathrm{Na}^{+}, \mathrm{K}^{+}, \mathrm{Mg}^{2+}$ and $\mathrm{Ca}^{2+}$ (Table 7 ). The precipitation of gypsum in the fractional and full crystallisation experiments was observed to occur over weeks, in accord with the slow kinetics of sulphate minerals at cold temperatures (Kargel, 1991; Hogenboom et al., 1995; Marion and Kargel, 2008). The gypsum solubility experiments at -23.7 and $-25.0{ }^{\circ} \mathrm{C}$ considered representative of the fractional crystallisation pathway (section 2.4), indicated that this compositional change is sufficient for the brine to become slightly supersaturated with respect to gypsum, resulting in its seeded precipitation (Table 5 and section 3.3). And so, the sea ice system appears to sustain a low gypsum supersaturation in the fractional crystallisation pathway within the ice-hydrohalite aggregate. In the tandem experiments, considered representative of the full crystallisation pathway, the presence of both mirabilite and gypsum seed in the experimental brine yielded mirabilite dissolution and gypsum precipitation in higher amounts than observed in the absence of mirabilite (Table 5 and section 3.3). These observations collectively indicate that, when all potential minerals are in contact with the brine in a sea ice system (full crystallisation pathway) at these cold temperatures, a positive feedback will occur for gypsum precipitation via mirabilite dissolution in the presence of hydrohalite, as was also observed by Gitterman (1937) and Marion et al. (1999).

Combining the maximum amount of gypsum precipitation measured here at $-25.0{ }^{\circ} \mathrm{C}\left(\Delta \mathrm{Ca}^{2+}=80.9 \mathrm{mmol} \mathrm{kg}{ }^{-1}\right.$ during full crystallisation; Table 5) 


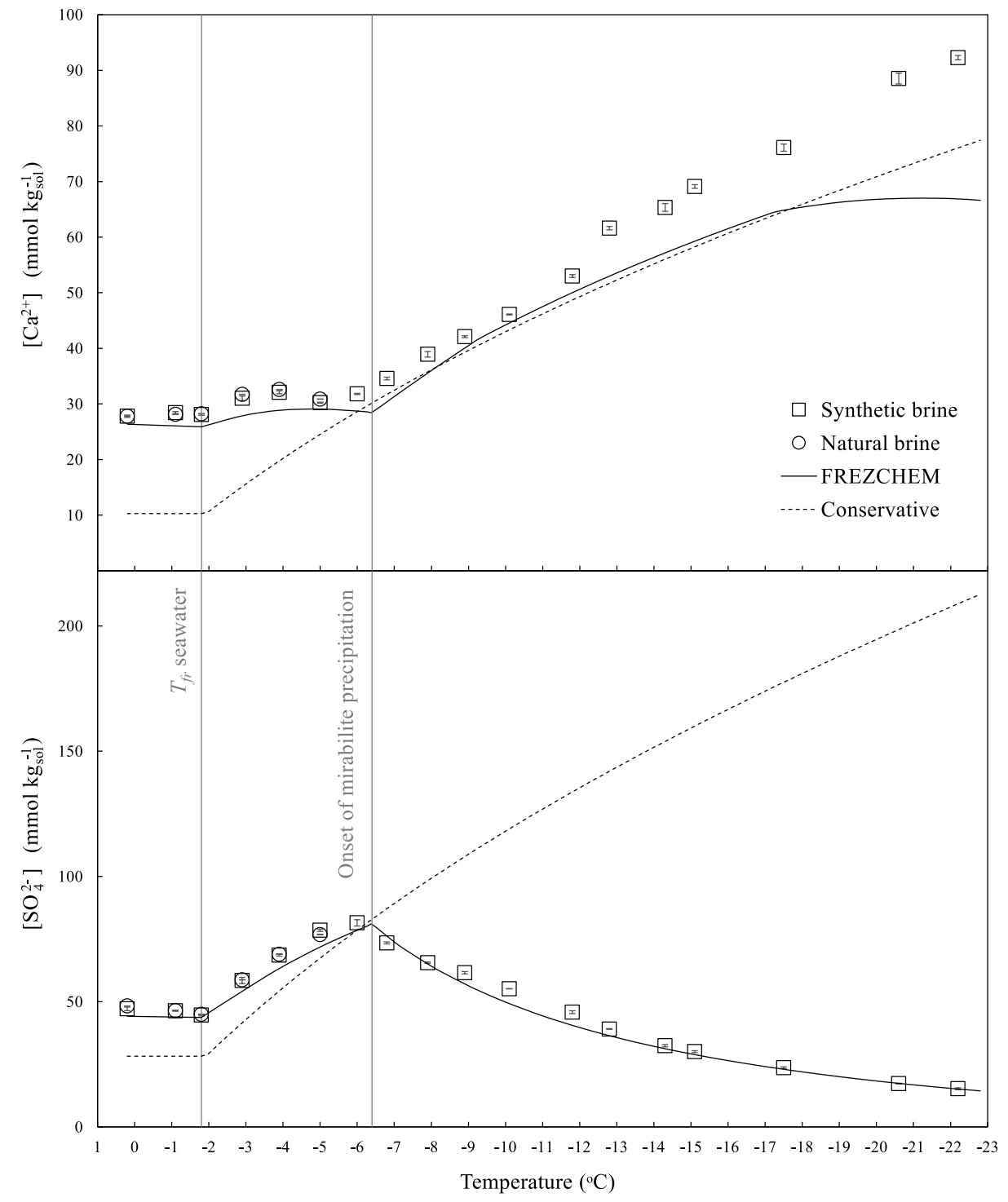

Figure 5: The equilibrium $\mathrm{Ca}^{2+}$ and $\mathrm{SO}_{4}^{2-}$ concentrations in sea ice brines between 0.2 and $-22.8^{\circ} \mathrm{C}$. Measured and modelled (FREZCHEM) values above $-6.4^{\circ} \mathrm{C}$ are at brine gypsum equilibrium, and those below $-6.4^{\circ} \mathrm{C}$ are at brine-mirabilite-gypsum equilibrium. The vertical line at $-1.8^{\circ} \mathrm{C}$ marks the point at which coupled changes in salinity and temperature occur as a result of freezing, whilst that at $-6.4{ }^{\circ} \mathrm{C}$ marks the onset of mirabilite precipitation. The dashed line represents the estimated concentration based on a conservatively concentrated solution at ice-brine equilibrium, computed using FREZCHEM with only ice enabled in the mineral database. 
with the FREZCHEM estimate of the residual brine mass at this temperature in a closed sea ice system (no brine drainage) from a starting practical salinity of $35 \mathrm{~g} \mathrm{~kg}^{-1}$ (64.9 $\mathrm{g}$ of brine per $\mathrm{kg}$ frozen seawater), we estimate a maximum gypsum concentration in bulk sea ice of $0.9 \mathrm{~g} \mathrm{~kg}^{-1}$ at $-25.0{ }^{\circ} \mathrm{C}$. In comparison, the estimated concentrations of mirabilite and hydrohalite in undrained bulk sea ice at the same temperature and full crystallisation pathway are 6.7 and $28.6 \mathrm{~g} \mathrm{~kg}^{-1}$, respectively.

\subsection{Hydrohalite solubility in sea ice brines}

The excellent agreement between the experimentally determined $p K_{\mathrm{sp} \text {,hydrohalite }}^{*}$ and that computed by FREZCHEM reflects the abundance of experimental data for hydrohalite used to parameterise the model. All experimental (Gitterman, 1937; Nelson and Thompson, 1954; this study) and model (Marion et al., 1999; Marion and Kargel, 2008) evidence is in agreement that hydrohalite precipitates in sea ice at $T \leqslant-22.9^{\circ} \mathrm{C}$, but its dynamics in undersaturated sea ice brines have never been investigated before. Between -14 and $-25^{\circ} \mathrm{C}$, the solubility of hydrohalite (Figure 3) displays two distinct temperature fields corresponding with the undersaturated and supersaturated brines (Figure 4 ), with a sharp inflection at $\Omega_{\text {hydrohalite }}=1$. This sharp change is reflected in the quantity of hydrohalite in a closed sea ice brine system (no brine drainage), which, by $-23.0{ }^{\circ} \mathrm{C}$, i.e., $0.1{ }^{\circ} \mathrm{C}$ into the temperature region in which its precipitation is viable in sea ice systems, amounts to 3.3 $\mathrm{g} \mathrm{kg}^{-1}$, and increases to $28.0 \mathrm{~g} \mathrm{~kg}^{-1}$ by $-26.0{ }^{\circ} \mathrm{C}$ (fractional crystallisation; Figure 6). Such quantities of hydrohalite are consistent with the formation of an ice-hydrohalite aggregate (Light et al., 2009; McCarthy et al., 2007; Butler and Kennedy, 2015).

Prior to the onset of hydrohalite precipitation, $\mathrm{Na}^{+}$and $\mathrm{Cl}^{-}$comprise $91.7 \%$ of the total mass of dissolved ions in the brine (FREZCHEM computation, Table 7). Upon hydrohalite precipitation, the reduced ionic strength of the brine from the removal of $\mathrm{Na}^{+}$and $\mathrm{Cl}^{-}$as hydrohalite promotes instantaneous ice formation to re-establish ice-brine equilibrium at these cold 
Table 7: FREZCHEM predictions of the major brine composition before $\left(-22.8^{\circ} \mathrm{C}\right)$ and after $\left(-26.0^{\circ} \mathrm{C}\right)$ hydrohalite precipitation. Each ion is presented as its percentage contribution to the mass of total salt. The output at $-26.0^{\circ} \mathrm{C}$ is for fractional crystallisation, which retains the brine at undersaturation with respect to mirabilite. The displayed percentages are implicit of less concentrated ions that are also specified in the composition of Standard Seawater (Millero et al., 2008), which include $\mathrm{HCO}_{3}^{-}, \mathrm{CO}_{3}^{2-}, \mathrm{NO}_{3}^{-}, \mathrm{Br}^{-}$, $\mathrm{B}(\mathrm{OH})_{4}^{-}, \mathrm{F}^{-}$and $\mathrm{CO}_{2}$. Ice, mirabilite and hydrohalite were the only solid phases enabled in the FREZCHEM database for this computation.

\begin{tabular}{lcc}
\hline & $-22.8{ }^{\circ} \mathrm{C}$ & $-26.0{ }^{\circ} \mathrm{C}$ \\
Ion & $S_{\mathrm{A}}=230.82 \mathrm{~g} \mathrm{~kg}_{\text {sol }}^{-1}$ & $S_{\mathrm{A}}=235.68 \mathrm{~g} \mathrm{~kg}_{\text {sol }}^{-1}$ \\
\hline$\% \mathrm{Na}^{+}$ & 29.89 & 20.00 \\
$\% \mathrm{~K}^{+}$ & 1.36 & 2.91 \\
$\% \mathrm{Mg}^{2+}$ & 4.36 & 9.31 \\
$\% \mathrm{Ca}^{2+}$ & 1.38 & 2.95 \\
$\% \mathrm{Cl}^{-}$ & 61.77 & 64.59 \\
$\% \mathrm{SO}_{4}^{2-}$ & 0.62 & 1.06 \\
\hline
\end{tabular}

temperatures, which concentrates the brine and results in further hydrohalite precipitation. This cycle of both ice and hydrohalite formation in tandem continues until ice-brine-hydrohalite equilibrium is attained; in the process, the volume of remaining brine diminishes. Between -22.8 and $-26{ }^{\circ} \mathrm{C}$ in a closed system modelled with FREZCHEM (1 kg of seawater, practical salinity $=35)$, the amount of ice increases from $857 \mathrm{~g}$ to $909 \mathrm{~g}$, which decreases the amount of liquid water from 105 to $41 \mathrm{~g}$ (Figure 7 ). In sea ice, this would equate to a reduction in brine volume by more than $60 \%$ within a $3{ }^{\circ} \mathrm{C}$ drop in temperature.

If hydrohalite precipitation in sea ice results in the formation of an icehydrohalite aggregate, then the in-situ properties of this solid may be analogous to those studied in the $\mathrm{NaCl}-\mathrm{H}_{2} \mathrm{O}$ system at its eutectic (McCarthy et al., 2007). The formation of an ice-hydrohalite aggregate may act as a hindrance for the hydrohalite-mirabilite-gypsum interaction with the residual brine of the full crystallisation pathway (Gitterman, 1937; Marion et al., 1999). Mirabilite crystals are understood to sink to the bottom of brine inclusions (Light et al., 2003); when hydrohalite forms as an aggregate with ice 
with the residual brine trapped in it, it will fill the available pore space and can consequently restrict further brine-mirabilite interaction. The result is a microstructure with very limited mixing and surface area for brine-mineral interaction, acting to limit the dissolution of mirabilite and the consequently enhanced precipitation of gypsum. Although the hydrohalite-mirabilite feedback was observed by Butler and Kennedy (2015), their experimental protocol required continual spinning of the sample, which may have promoted mineral interaction with brine by mixing as the sample warmed and cooled. The determination of which crystallisation pathway occurs in the temperature field of hydrohalite precipitation in natural sea ice conditions requires further investigation, and would likely require in-situ measurements in controlled laboratory conditions that replicate those in sea ice.

\subsection{Hydrohalite modelling in first-year sea ice}

The dynamics of hydrohalite in first-year sea ice are outlined here based on the FREZCHEM output, confirmed by the current hydrohalite solubility data, and a 1D empirical model of sea ice growth and desalination. The FREZCHEM output of the mass of hydrohalite to precipitate in a $1 \mathrm{~kg}$ parcel of frozen seawater (Figure 6) was fitted to a stepwise polynomial function of temperature (Table 2, rows 11 and 12). This data was integrated (via equation 2) into a 1D model simulation of the vertical temperature and salinity profiles of snow-free first-year sea ice in the Arctic Basin as it grows over winter months, yielding hydrohalite concentration profiles within the ice pack at selected intervals (Figure 8). The temperature at the surface of the modelled ice pack drops below $-22.9{ }^{\circ} \mathrm{C}$ after 1 month (early November) from the onset of freezing when the ice pack is $73.5 \mathrm{~cm}$ thick and the incoming shortwave radiation for the region is $0 \mathrm{~W} \mathrm{~m}^{-2}$. Between early November and late February, the modelled ice pack thickens to $210 \mathrm{~cm}$, while the surface temperature decreases to $-32.1{ }^{\circ} \mathrm{C}$. Given the absence of sunlight and low temperatures, these conditions likely represent the most challenging and least studied aspects of Arctic sea ice dynamics. 


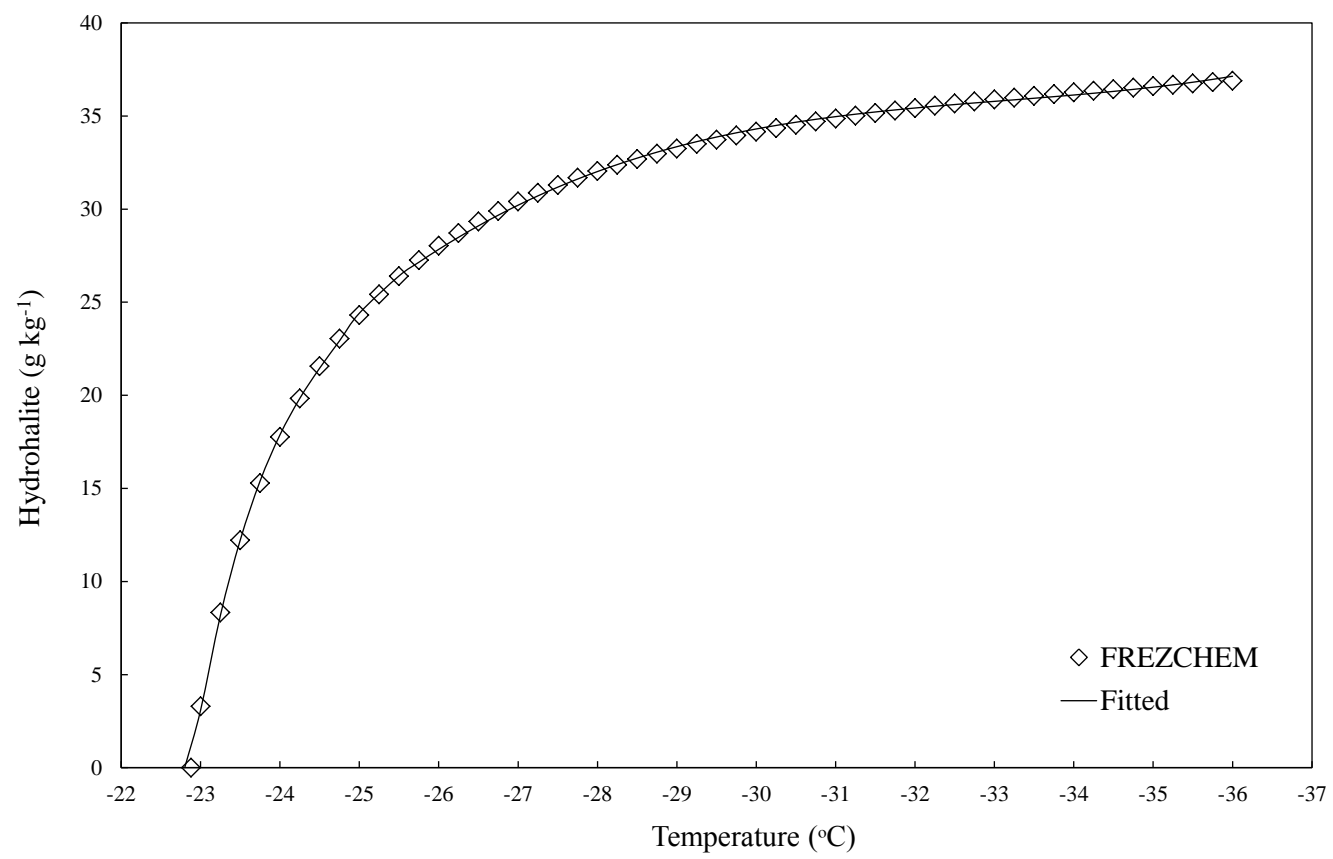

Figure 6: The weight of hydrohalite predicted to precipitate from $1 \mathrm{~kg}$ of seawater (practical salinity $=35$ ) between -22.9 and $-36{ }^{\circ} \mathrm{C}$ (fractional crystallisation). Also plotted is the fitted relationship of hydrohalite concentration $\left(\mathrm{g} \mathrm{kg}^{-1}\right)$ as a function of temperature (using equation 1) described by coefficients given in Table 2 .

As the ice pack thickens and the surface temperature decreases, the modelled hydrohalite concentration increases (Figure 8). When the ice pack is 75 $\mathrm{cm}$ thick, hydrohalite is only present in the upper $1 \mathrm{~cm}$ but, as the winter progresses, the vertical distribution of hydrohalite extends well below the ice surface, and by mid-February, when the ice is over $2 \mathrm{~m}$ thick, hydrohalite is present within the upper $65 \mathrm{~cm}$. The depth distribution of hydrohalite in the ice is governed by the bulk sea ice salinity and the temperature-related solubility changes leading to precipitation (Figure 6), while the sea ice temperature is assumed to have a linear depth distribution between the ice-air and ocean-ice interfaces (Cox and Weeks, 1988; Butler et al., 2016b). As a result of these two forcings, hydrohalite develops an S-shaped depth profile as the ice pack grows, reaching a maximum concentration below the ice-air 


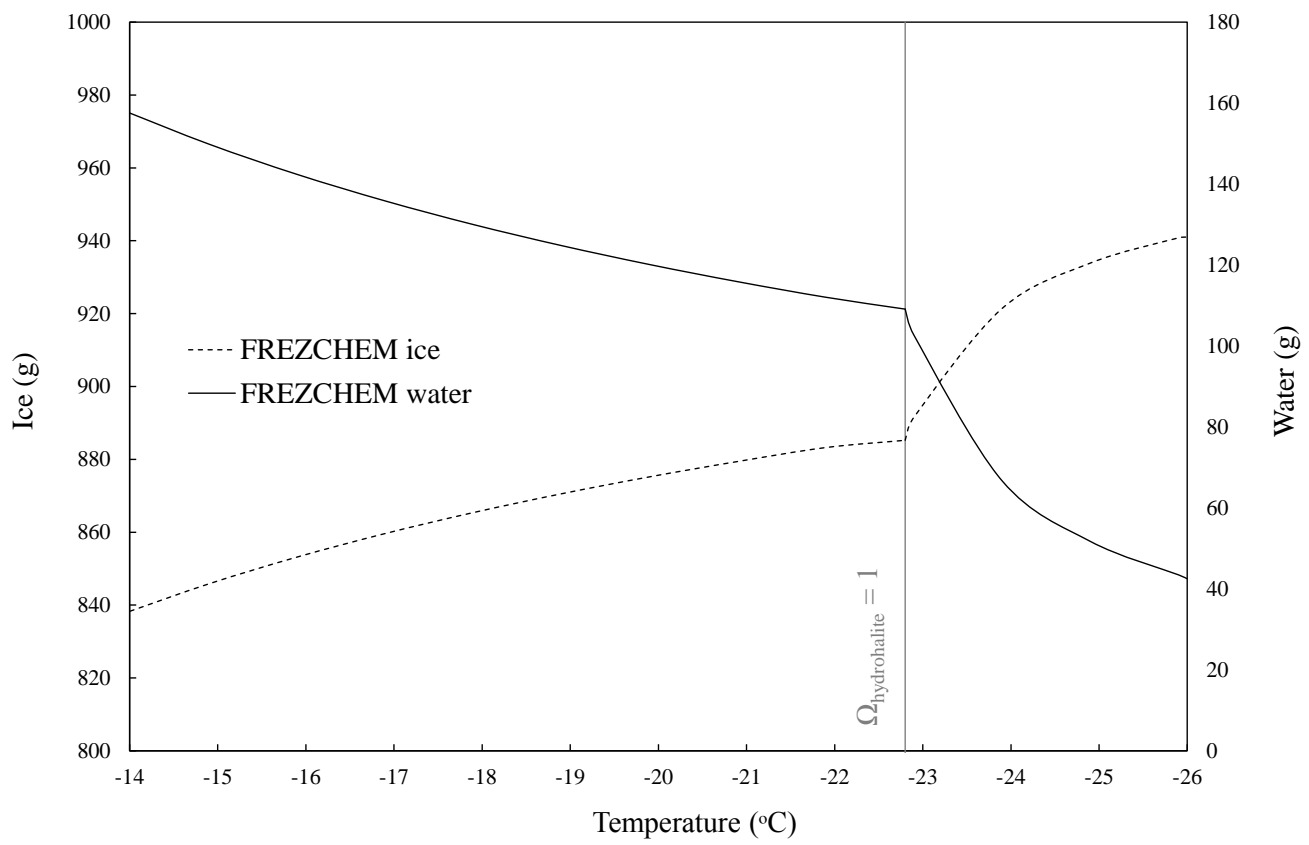

Figure 7: FREZCHEM predictions of the change in ice and water content in $1 \mathrm{~kg}$ of frozen seawater (practical salinity $=35$ ) between -14 and $-26{ }^{\circ} \mathrm{C}$ (fractional crystallisation). The vertical line at $-22.9{ }^{\circ} \mathrm{C}$ marks the point of which the system begins to become affected by precipitation of an ice-hydrohalite aggregate.

interface of $9.9 \mathrm{~g} \mathrm{~kg}^{-1}$.

Based on its solubility-temperature relationship (Figures 3, 4 and 6), the occurrence of hydrohalite in sea ice could display considerable daily or localised shifts between precipitation and dissolution in response to local weather patterns. Given that hydrohalite precipitation did not initiate within the modelled ice pack until incoming shortwave radiation had reduced to $0 \mathrm{~W} \mathrm{~m}^{-2}$, its contribution to the albedo feedback mechanism (Light et al., 2004; Carns et al., 2015) in polar environments seems limited, and is likely to be more relevant to the energy balance of 'Snowball Earth' during the Neoproterozoic (Light et al., 2009; Carns et al., 2015). Furthermore, the winter conditions in which hydrohalite precipitates likely hinder its identification and the examination of its dynamics in the sea ice system in the field. 


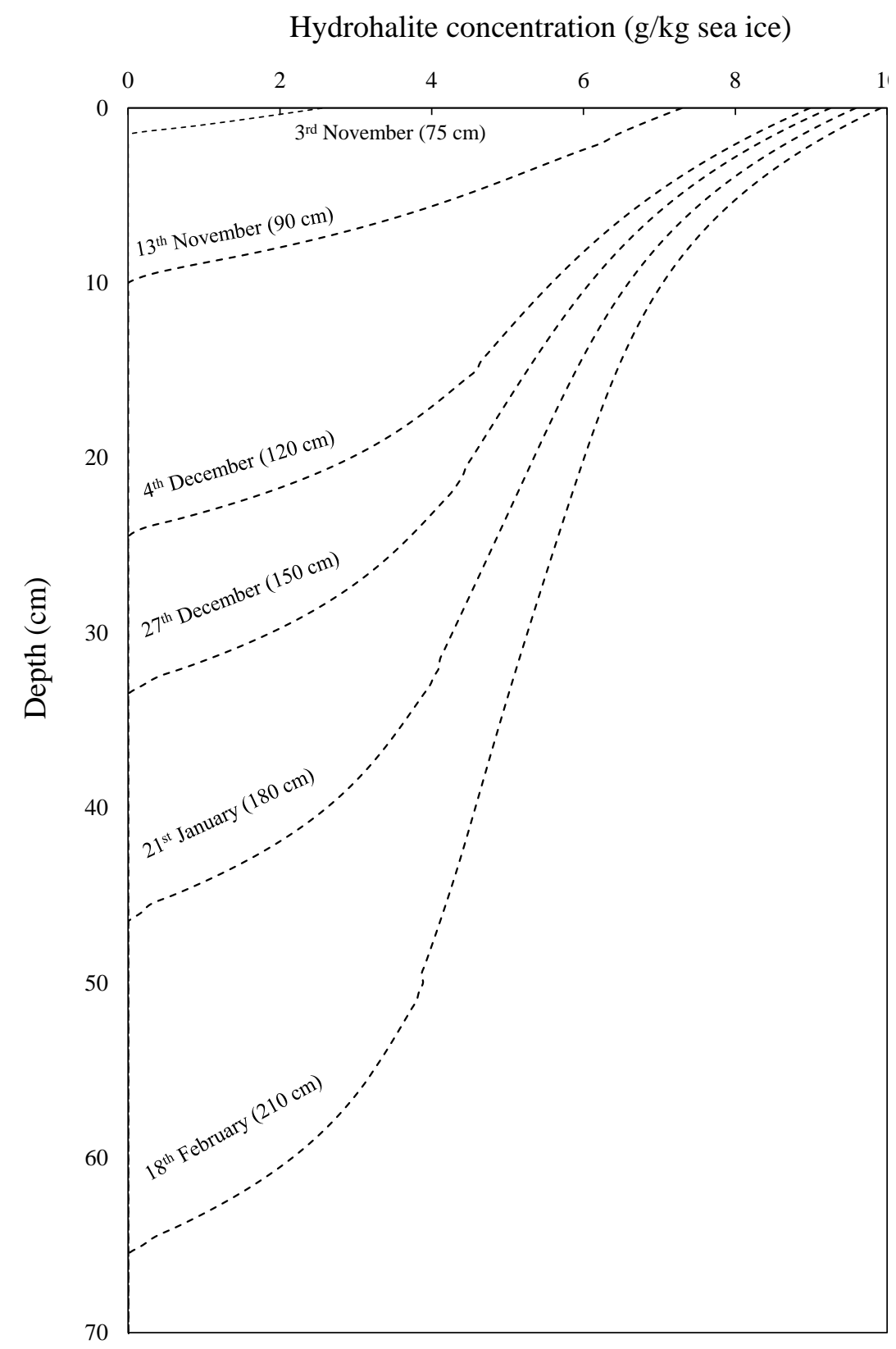

Figure 8: Modelled hydrohalite concentrations during the formation of first-year snow-free sea ice in the Arctic Basin. The full depth of the ice pack is not displayed, but is instead annotated at each increment.

4.6. The occurrence of gypsum in sea ice

The available mirabilite (Butler etsal., 2016b), gypsum, and hydrohalite solubility data (this study) can be used to evaluate the potential for occur- 
rence of gypsum in sea ice. The tendency of gypsum formation is strongly constrained by $\mathrm{SO}_{4}^{2-}$ availability in the brine, first, due to mirabilite precipitation at temperatures $\leqslant-6.4{ }^{\circ} \mathrm{C}$ and, subsequently, via mirabilite dissolution at temperatures $\leqslant-22.9{ }^{\circ} \mathrm{C}$. The recent identification of gypsum in experimental and natural sea ice at temperatures between -1.9 and $-10{ }^{\circ} \mathrm{C}$ (Geilfus et al., 2013) is not consistent with the systematic gypsum undersaturation observed here between 0.2 and $-22.2{ }^{\circ} \mathrm{C}$ in the presence of mirabilite (section 4.1 and Figure 2). Furthermore, the gypsum crystals identified in the experimental sea ice formed during the freezing of synthetic seawater that was deficient in $\mathrm{Ca}^{2+}$ and $\mathrm{SO}_{4}^{2-}$ by $17 \%$ and $40 \%$, respectively, relative to Standard Seawater (Geilfus et al., 2013). The deficiency of this solution with respect to the ionic constituents of gypsum would only act to impede this mineral from attaining saturation within the brine in the reported temperature range that includes the temperature region of mirabilite precipitation. Our experiments showed that brines in metastable mirabilite supersaturation state can attain low gypsum supersaturation leading to precipitation of this $\mathrm{CaSO}_{4}$ polymorph in small amounts, which will be likely transient in the presence of mirabilite given its dominant control on the availability of sulphate ions in the brine. It is possible that the brief storage ( $<3$ hours) of sea ice samples $<-25{ }^{\circ} \mathrm{C}$ prior to analysis carried out by Geilfus et al. (2013) allowed gypsum precipitation, which could become enhanced if hydrohalitemirabilite-gypsum interaction with brine is facilitated, but the quantity of gypsum formed in this way would be small $\left(<0.3 \mathrm{~g} \mathrm{~kg}_{\text {sea ice }}^{-1}\right.$ at a bulk salinity of $12 \mathrm{~g} \mathrm{~kg}^{-1}$ ) even if chemical equilibrium is attained.

Finally, the gypsum crystals that were observed in experimental and natural sea ice (Geilfus et al., 2013) may not have been authigenic but allochthonous. Though the gypsum crystals were identified as authigenic based on their grain morphology (Geilfus et al., 2013), gypsum is also a common mineral in aerosol particles (Prospero et al., 1981; Schütz and Sebert, 1987; Zimmermann et al., 2008) which are understood to be the source of its pres- 
ence in ice cores taken from the Greenland Ice Sheet (Biscaye et al., 1997; Steffensen, 1997). Gypsum can persist in an ice sheet due to its sparing solubility in aqueous solutions (Steffensen, 1997). Therefore, gypsum may not occur authigenically in brine inclusions but in aerosols settling on, and encapsulated in, sea ice, and may be sufficiently stable kinetically to allow extraction and identification even when the conditions in the brine pockets are undersaturated with respect to gypsum. Given this generated understanding about gypsum dynamics in sea ice from solubility measurements, particularly with respect to its undersaturation in all conditions above $-6.4{ }^{\circ} \mathrm{C}$, its potential as a marine deposit in polar seas (Geilfus et al., 2013) seems limited.

\section{Conclusions}

The determination of gypsum and hydrohalite solubilities in seawater (gypsum) and seawater-derived brines (gypsum and hydrohalite) allowed investigation of the dynamics of each mineral within the sea ice system. Gypsum solubility changed substantially between 0.2 and $-25.0^{\circ} \mathrm{C}$, displaying maximum solubility (i.e., minimum values for the stoichiometric equilibrium solubility product) in the temperature range from $-6{ }^{\circ} \mathrm{C}$ to $-10{ }^{\circ} \mathrm{C}$, with decreasing solubility at warmer and colder temperatures. The precipitation of gypsum is affected by the precipitation of mirabilite at temperatures below $-6.4^{\circ} \mathrm{C}$. When mirabilite is the dominant $\mathrm{SO}_{4}^{2-}$ sink in sea ice, the brines remain undersaturated with respect to gypsum to $-22.2{ }^{\circ} \mathrm{C}$. Gypsum is viable as a transient phase in conditions of metastable mirabilite supersaturation as observed in this study at -7.1 and $-8.2{ }^{\circ} \mathrm{C}$ but potentially applicable to occurrences of increased metastable mirabilite supersaturation at colder temperatures. Upon the onset of hydrohalite precipitation at temperatures below $-22.9^{\circ} \mathrm{C}$, gypsum can precipitate and, when the brine-mirabilite reaction is viable in these cold temperatures, mirabilite dissolution consequent on hydrohalite precipitation can enhance the amount of gypsum precipitate 
to approximately $0.9 \mathrm{~g} \mathrm{~kg}^{-1}$ (closed seawater system) at $-25.0{ }^{\circ} \mathrm{C}$.

The solubility of hydrohalite in sea ice decreases with temperature, and this decrease displays a sharp change at $-22.9^{\circ} \mathrm{C}$, resulting in distinct temperature fields of undersaturated and supersaturated brines. The sharp change in hydrohalite solubility at temperatures below $-22.9^{\circ} \mathrm{C}$ results from the formation of an ice-hydrohalite aggregate. During this process, ice and hydrohalite form cooperatively as an intergrowth, likely displaying similar properties to the eutectic aggregates from binary $\mathrm{NaCl}-\mathrm{H}_{2} \mathrm{O}$ systems (McCarthy et al., 2007). This heterogeneous mixture can fill the sea ice pores and channels, and results in strong compositional changes in the little brine that remains at these cold temperatures, affecting the microstructure of the ice substantially.

The observed gypsum solubility is consistently underestimated by the thermodynamic FREZCHEM code. This inconsistency was assessed here to be associated with the discrepancy in the equilibrium $\mathrm{Ca}^{2+}$ concentration, likely due to the model being extrapolated into an experimentally unknown region. In contrast the measured and FREZCHEM-based hydrohalite solubilities display excellent agreement (within experimental error). Based on the reliable FREZCHEM output of hydrohalite equilibria, a temperature function of the hydrohalite mass in a closed sea ice system was incorporated into a 1D model for the growth of Arctic sea ice. The model output of the distribution of hydrohalite with time and depth in sea ice showed that hydrohalite should be present in the upper layers of the ice pack once the incoming shortwave radiation drops to $0 \mathrm{~W} \mathrm{~m}^{-2}$, extending down to a depth of $65 \mathrm{~cm}$ in the ice from a $9.9 \mathrm{~g} \mathrm{~kg}^{-1}$ surface concentration maximum at maximal ice thickness. This suggests a critical role for hydrohalite in modifying the physical and chemical properties of the sea ice brine inclusions but limited hydrohalite effect on the albedo of sea ice. 


\section{Acknowledgements}

The work was supported by a NERC Algorithm Studentship (NE/K501013), beamtime awards EE-3897-1, EE-12301-01 and EE14575-1 from Diamond Light Source Ltd., and a PhD Student Grant from the International Association of Geochemistry. We thank the two anonymous reviewers for their constructive comments, which helped to improve this paper. All data presented here are freely available upon contacting the corresponding author.

\section{References}

Assur, A., 1960. Composition of sea ice and its tensile strength. Tech. rep., 44, Arctic Sea Ice, U.S. National Academy of Sciences, National Research Council, U.S.A.

Berner, R. A., 1980. Early diagenesis: A theoretical approach. Princeton series in geochemistry. Princeton University Press.

Biscaye, P. E., Grousset, F. E., Revel, M., Van der Gaast, S., Zielinski, G. A., Vaars, A., Kukla, G., 1997. Asian provenance of glacial dust (stage 2) in the Greenland Ice sheet Project 2 Ice Core, Summit, Greenland. Journal of Geophysical Research: Oceans 102 (C12), 26765-26781.

Boeyens, J. C. A., Ichharam, V. V. H., 2002. Redetermination of the crystal structure of calcium sulphate dihydrate, $\mathrm{CaSO}_{4} \cdot 2 \mathrm{H}_{2} \mathrm{O}$. Zeitschrift fur Kristallographie 217, 9-19.

Brand, H. E. A., Fortes, A. D., Wood, I. G., Knight, K. S., Vočadlo, L., 2009. The thermal expansion and crystal structure of mirabilite $\left(\mathrm{Na}_{2} \mathrm{SO}_{4} \cdot 10 \mathrm{D}_{2} \mathrm{O}\right)$ from 4.2 to $300 \mathrm{~K}$, determined by time-of-flight neutron powder diffraction. Physics and Chemistry of Minerals 36 (1), 29-46.

Butler, B. M., Kennedy, H., 2015. An investigation of mineral dynamics in frozen seawater brines by direct measurement with synchrotron X-ray pow- 
der diffraction. Journal of Geophysical Research: Oceans 120 (8), 56865697.

Butler, B. M., Papadimitriou, S., Kennedy, H., 2016a. The effect of mirabilite precipitation on the absolute and practical salinities of sea ice brines. Marine Chemistry 184, 21-31.

Butler, B. M., Papadimitriou, S., Santoro, A., Kennedy, H., 2016b. Mirabilite solubility in equilibrium sea ice brines. Geochimica et Cosmochimica Acta $182,40-54$.

Carns, R. C., Brandt, R. E., Warren, S. G., 2015. Salt precipitation in sea ice and its effect on albedo, with application to Snowball Earth. Journal of Geophysical Research: Oceans 120 (11), 7400-7412.

Coelho, A., 2012. TOPAS-Academic V5.

URL http: //www.topas-academic.net/

Cox, G. F. N., Weeks, W. F., 1988. Numerical simulations of the profile properties of undeformed first-year sea ice during the growth season. Journal of Geophysical Research: Oceans 93 (C10), 12449-12460.

Dieckmann, G. S., Nehrke, G., Papadimitriou, S., Göttlicher, J., Steininger, R., Kennedy, H., Wolf-Gladrow, D., Thomas, D. N., 2008. Calcium carbonate as ikaite crystals in Antarctic sea ice. Geophysical Research Letters 35 (8), L08501.

Fischer, M., Thomas, D. N., Krell, A., Nehrke, G., Göttlicher, J., Norman, L., Meiners, K. M., Riaux-Gobin, C., Dieckmann, G. S., 2013. Quantification of ikaite in Antarctic sea ice. Antarctic Science 25 (3), 421-432.

Geilfus, N. X., Galley, R. J., Cooper, M., Halden, N., Hare, A., Wang, F., Søgaard, D. H., Rysgaard, S., 2013. Gypsum crystals observed in experimental and natural sea ice. Geophysical Research Letters 40 (24), 63626367. 
Gitterman, K. E., 1937. Thermal analysis of seawater. Tech. rep., CRREL TL287, USA Cold Region Research and Engineering Laboratory, Hanover, N.H.

He, S., Morse, J. W., 1993. The carbonic acid system and calcite solubility in aqueous $\mathrm{Na}-\mathrm{K}-\mathrm{Ca}-\mathrm{Mg}-\mathrm{Cl}-\mathrm{SO}_{4}$ solutions from 0 to $90{ }^{\circ} \mathrm{C}$. Geochimica et Cosmochimica Acta 57 (15), 3533-3554.

Hillier, S., 2003. Quantitative analysis of clay and other minerals in sandstones by X-ray powder diffraction (XRPD). Blackwell Publishing Ltd., pp. 213-251.

Hogenboom, D. L., Kargel, J. S., Ganasan, J. P., Lee, L., 1995. Magnesium sulfate-water to $400 \mathrm{MPa}$ using a novel piezometer: Densities, phase equilibria, and planetological implications. Icarus 115 (2), 258-277.

Howarth, R. W., 1978. A rapid and precise method for determining sulfate in seawater, estuarine waters, and sediment pore waters. Limnology and Oceanography 23 (5), 1066-1069.

Kargel, J. S., 1991. Brine volcanism and the interior structures of asteroids and icy satellites. Icarus 94, 368-390.

Klewe, B., Pederson, B., 1974. The crystal structure of sodium chloride dihydrate. Acta Crystallographica B30, 2363-2371.

Le Bail, A., Duroy, H., Fourquet, J. L., 1988. Ab-initio structure determination of lisbwo 6 by X-ray powder diffraction. Materials Research Bulletin $23(3), 447-452$.

Light, B., Brandt, R. E., Warren, S. G., 2009. Hydrohalite in cold sea ice: Laboratory observations of single crystals, surface accumulations, and migration rates under a temperature gradient, with application to Snowball Earth. Journal of Geophysical Research 114 (C7), C07018. 
Light, B., Maykut, G. A., Grenfell, T. C., 2003. Effects of temperature on the microstructure of first-year Arctic sea ice. Journal of Geophysical Research 108 (C2), 3051.

Light, B., Maykut, G. A., Grenfell, T. C., 2004. A temperature-dependent, structural-optical model of first-year sea ice. Journal of Geophysical Research 109, C06013.

Marion, G. M., 2001. Carbonate mineral solubility at low temperatures in the $\mathrm{Na}-\mathrm{K}-\mathrm{Mg}-\mathrm{Ca}-\mathrm{H}-\mathrm{Cl}-\mathrm{SO}_{4}-\mathrm{OH}-\mathrm{HCO}_{3}-\mathrm{CO}_{3}-\mathrm{CO}_{2}-\mathrm{H}_{2} \mathrm{O}$. Geochimica et Cosmochimica Acta 65 (12), 1883-1896.

Marion, G. M., Catling, D. C., Kargel, J. S., Crowley, J. K., 2016. Modeling calcium sulfate chemistries with applications to Mars. Icarus 278, 31-37.

Marion, G. M., Farren, R. E., 1997. Gypsum solubility at subzero temperatures. Soil Science Society of America Journal 61, 1666-1671.

Marion, G. M., Farren, R. E., 1999. Mineral solubilities in the $\mathrm{Na}-\mathrm{K}-\mathrm{Mg}-$ $\mathrm{Ca}-\mathrm{Cl}-\mathrm{SO}_{4}-\mathrm{H}_{2} \mathrm{O}$ system: A re-evaluation of the sulfate chemistry in the Spencer-Moller-Weare model. Geochimica et Cosmochimica Acta 63 (9), 1305-1318.

Marion, G. M., Farren, R. E., Komrowski, A. J., 1999. Alternative pathways for seawater freezing. Cold Regions Science and Technology 29, 259-266.

Marion, G. M., Grant, S. G., 1994. FREZCHEM: A chemical thermodynamic model for qqueous solutions at subzero temperatures. Tech. rep., DTIC Document.

Marion, G. M., Kargel, J. S., 2008. Cold Aqueous Planetary Geochemistry with FREZCHEM. Springer, Heidelberg. 
McCarthy, C., Cooper, R. F., Kirby, S. H., Rieck, K. D., Stern, L. A., 2007. Solidification and microstructures of binary ice-I/hydrate eutectic aggregates. American Mineralogist 92 (10), 1550-1560.

Millero, F. J., Feistel, R., Wright, D. G., McDougall, T. J., 2008. The composition of Standard Seawater and the definition of the ReferenceComposition Salinity Scale. Deep Sea Research Part I 55, 50-72.

Millero, F. J., Leung, W. H., 1976. The thermodynamics of seawater at one atmosphere. American Journal of Science 276 (9), 1035-1077.

Mucci, A., 1983. The solubility of calcite and aragonite in seawater at various salinities, temperatures, and one atmosphere total pressure. American Journal of Science 283, 780-799.

Nelson, K. H., Thompson, T. G., 1954. Deposition of salts from sea water by frigid concentration. Tech. rep., 29, Office of Naval Research, Arlington, VA.

Papadimitriou, S., Kennedy, H., Kennedy, P., Thomas, D. N., 2013. Ikaite solubility in seawater-derived brines at $1 \mathrm{~atm}$ and sub-zero temperatures to 265 K. Geochimica et Cosmochimica Acta 109, 241-253.

Papadimitriou, S., Loucaides, S., Rérolle, V., Achterberg, E. P., Dickson, A. G., Mowlem, M., Kennedy, H., 2016. The measurement of pH in saline and hypersaline media at sub-zero temperatures: Characterization of Tris buffers. Marine Chemistry 184, 11-20.

Petrich, C., Eicken, H., 2010. Growth, structure and properties of sea ice. Sea Ice 2, 23-77.

Prospero, J., Glaccum, R., Nees, R., 1981. Atmospheric transport of soil dust from Africa to South America. Nature 289, 570-572. 
Raju, K. U., Atkinson, G., 1990. The thermodynamics of scale mineral solubilities. III, Calcium sulfate in aqueous $\mathrm{NaCl}$. Journal of chemical and engineering data 35 (3), 361-367.

Richardson, C., 1976. Phase relationships in sea ice as a function of temperature. Journal of Glaciology 17 (77), 507-519.

Rietveld, H. M., 1969. A profile refinement method for nuclear and magnetic structures. Journal of Applied Crystallography 2 (2), 65-71.

Schütz, L., Sebert, M., 1987. Mineral aerosols and source identification. Journal of Aerosol Science 18 (1), 1-10.

Steffensen, J. P., 1997. The size distribution of microparticles from selected segments of the Greenland Ice Core Project ice core representing different climatic periods. Journal of Geophysical Research: Oceans 102 (C12), 26755-26763.

Thomas, D., Dieckmann, G., 2002. Antarctic sea ice-a habitat for extremophiles. Science 295 (5555), 641-644.

Wang, Y. W., Kim, Y. Y., Christenson, H. K., Meldrum, F. C., 2012. A new precipitation pathway for calcium sulfate dihydrate (gypsum) via amorphous and hemihydrate intermediates. Chemical Communications 48 (4), 504-506.

Zimmermann, F., Weinbruch, S., Schütz, L., Hofmann, H., Ebert, M., Kandler, K., Worringen, A., 2008. Ice nucleation properties of the most abundant mineral dust phases. Journal of Geophysical Research: Atmospheres 113 (D23), d23204. 